\title{
Investigation of Water-Logged Spent Fuel Rods under Dry Storage Conditions
}

September 1986

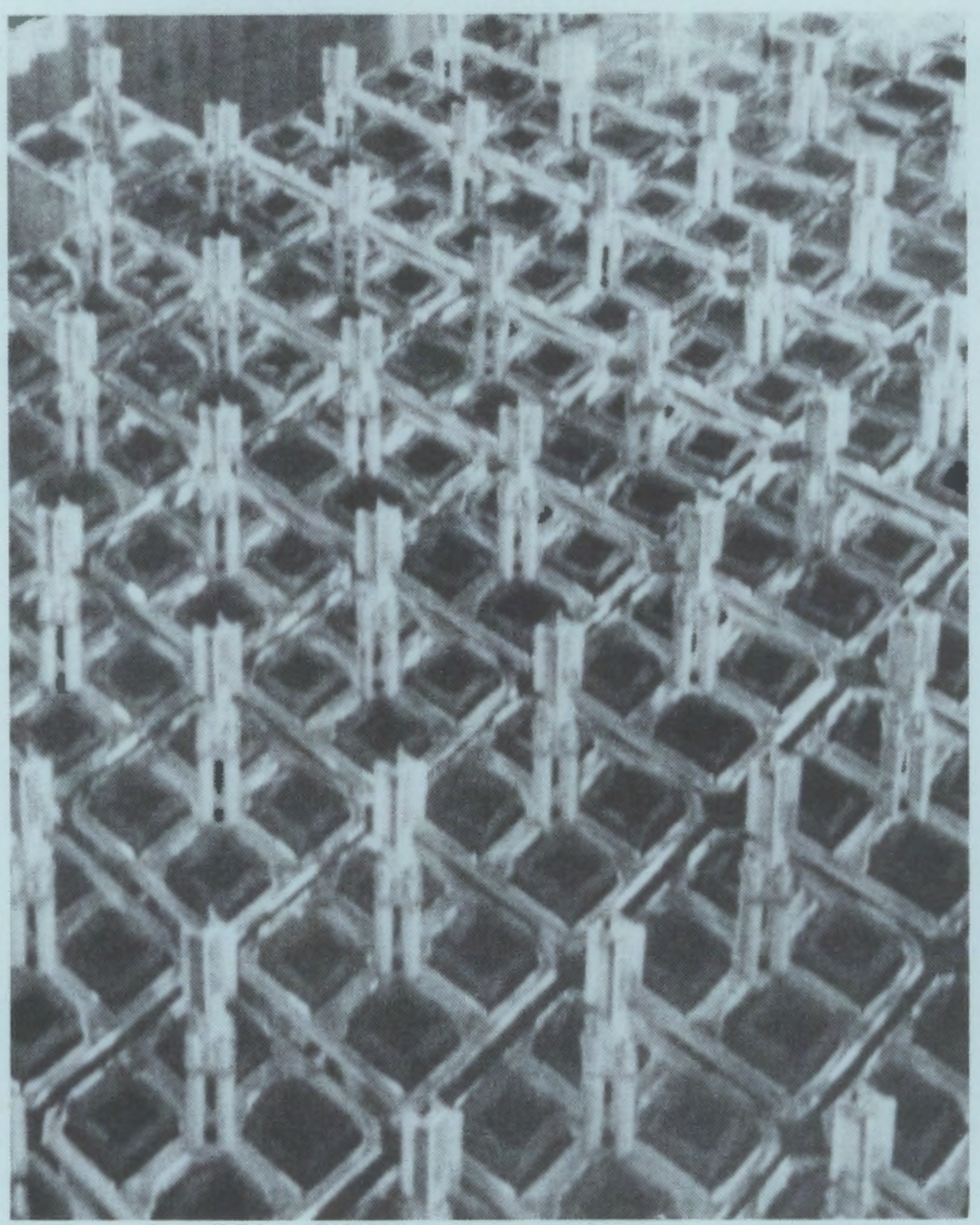

Prepared by Battelle, Columbus Division

for Pacific Northwest Laboratory and

the U.S. Department of Energy

under Contract DE-AC06-76RLO 1830

Pacific Northwest Laboratory

Operated for the U.S. Department of Energy

by Battelle Memorial Institute 


\title{
DISCLAIMER
}

This report was prepared as an account of work sponsored by an agency of the United States Government. Neither the United States Government nor any agency thereof, nor Battelle Memorial Institute, nor any of their employees, makes any warranty, expressed or implied, or assumes any legal liability or responsibility for the accuracy, completeness, or usefulness of any information, apparatus, product, or process disclosed, or represents that its use would not infringe privately owned rights. Reference herein to any specific commercial product, process, or service by trade name, trademark, manufacturer, or otherwise, does not necessarily constitute or imply its endorsement, recommendation, or favoring by the United States Government of any agency thereof, or Battelle Memorial Institute. The views and opinions of authors expressed herein do not necessarly state or reflect those of the United States Government or any agency thereof, or Battelle Memorial Institute.

\author{
PACIFIC NORTHWEST LABORATORY \\ operated by \\ BATTELLE \\ for the \\ UNITED STATES DEPARTMENT OF ENERGY \\ under Contract DE-AC06-76RLO 1830
}

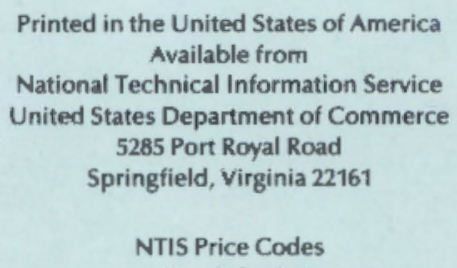


PNL-5987

UC -85

INVESTIGATION OF WATER-LOGGED

SPENT FUEL RODS UNDER

DRY STORAGE CONDITIONS

R. Kohli

V. Pasupathi

Battelle Columbus Division

Columbus, Ohio 43201

E. R. Gilbert, PNL. Proyram Manager

September 1986

Prepared by Battelle Columbus Division

for Pacific Northwest Laboratory

under Contract DE-AC06-76RLO 1830

with the U.S. Department of Energy

Pacific Northwest Laboratory

Richland, Washington 99352 
I

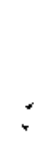

' 
Tests were conducted to determine the amount of moisture contained in breached, water-logged spent fuel rods and the rate of release. Two wellcharacterized BWR fuel rods with reactor-induced breaches were tested in a hot ce11. These rods contained approximately 6 to $10 \mathrm{~g}$ of moisture, most of which was released during heating tests simulating normal cask drying operations. Additional testing with two intentionally defected fuel rods (BWR and PWR) was performed to evaluate the effect of the cladding breach on inigration of moisture along the length of the fuel rod. The results showed that the moisture released from reactor-breached spent fuel rods was insufficient to cause degradation of fuel or dry storage system components. 


\section{ACKNOWLEDGMENTS}

The work discussed in this report was supported by the U.S. Department of Energy, Office of Civilian Radioactive Waste Management through the Commercial Spent Fuel Management Division of the Richland Operations Office. The project was managed through the PNL Commercial Spent Fuel Management Program Office.

The authors are very grateful to A. B. Johnson, Jr. and E. R. Gilbert (Pacific Northwest Laboratory) and M. C. Matthews (Battelle Columbus Division) for useful discussions. Appreciation is also expressed to M. B. Berchtold, P. E. Tomlin, and T. A. Beddick (Battelle Columbus Division) for performance of the hot cell work. 


\section{CONTENTS}

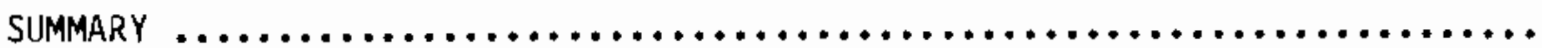

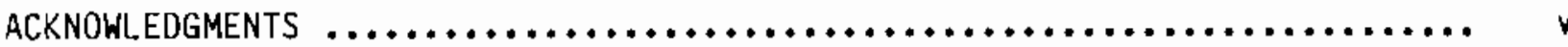

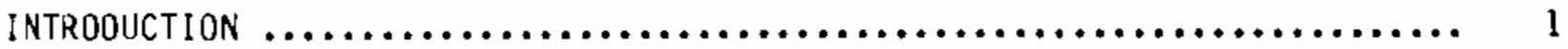

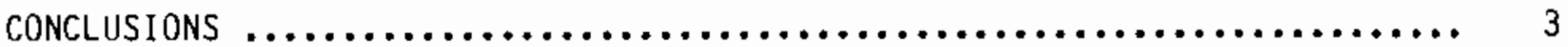

PRE-TEST CHARACTERIZATION OF FUEL RODS $\ldots \ldots \ldots \ldots \ldots \ldots \ldots \ldots \ldots \ldots \ldots \ldots \ldots \ldots$

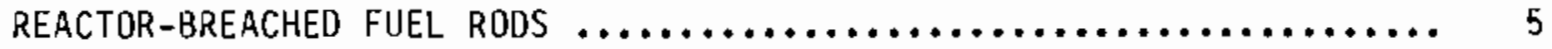

INTENTIONALLY OEFECTED FUEL RODS $\ldots \ldots \ldots \ldots \ldots \ldots \ldots \ldots \ldots \ldots \ldots \ldots \ldots \ldots$

TEST DESIGN $\ldots \ldots \ldots \ldots \ldots \ldots \ldots \ldots \ldots \ldots \ldots \ldots \ldots \ldots \ldots \ldots \ldots \ldots \ldots \ldots \ldots \ldots \ldots \ldots$

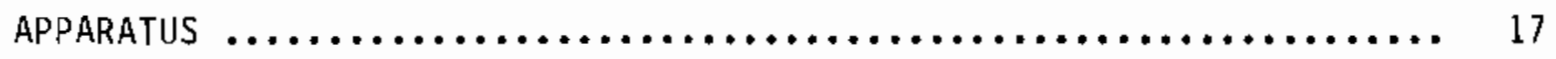

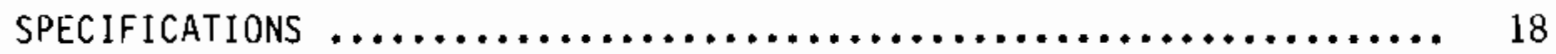

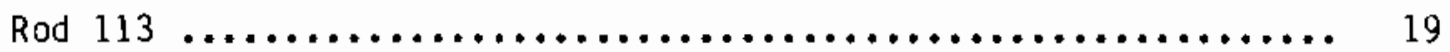

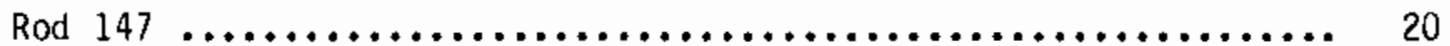

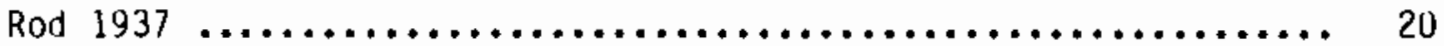

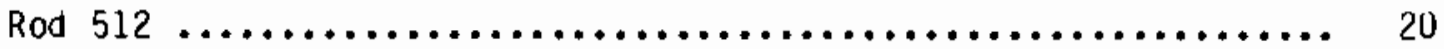

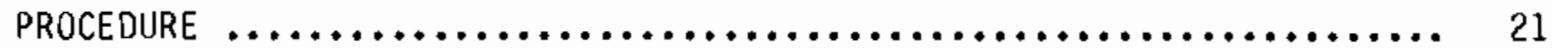

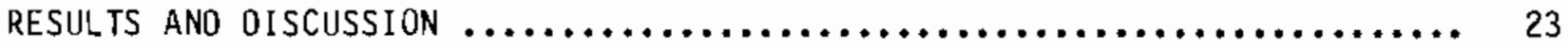

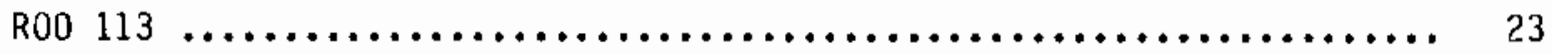

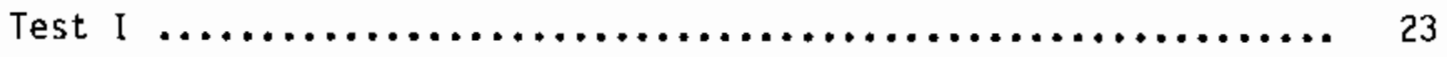

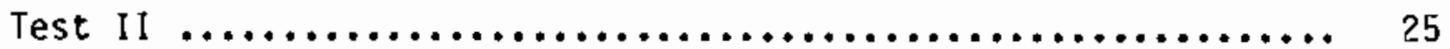

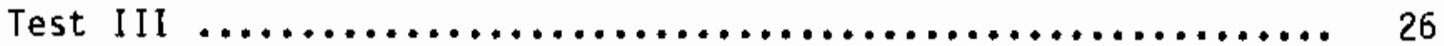

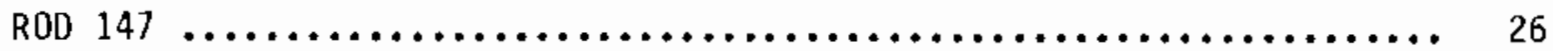

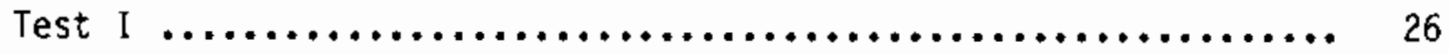

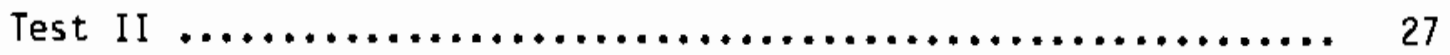

Test III $\ldots \ldots \ldots \ldots \ldots \ldots \ldots \ldots \ldots \ldots \ldots \ldots \ldots \ldots \ldots \ldots \ldots \ldots \ldots \ldots \ldots 27$ 


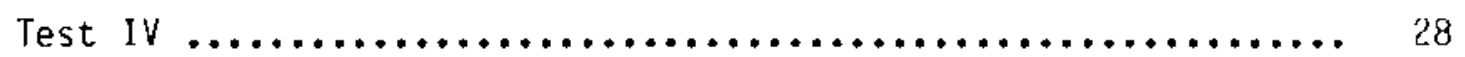

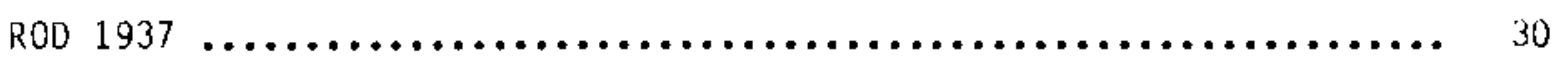

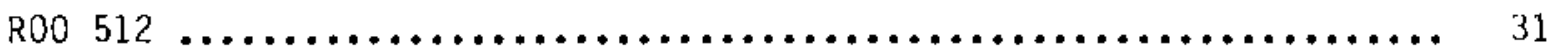

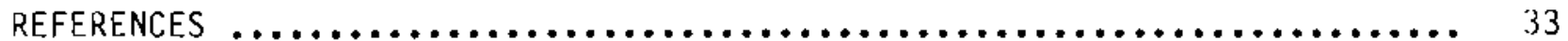




\section{FIGURES}

1 Breaches in Fuel Rod 147 at Different Axial Locations

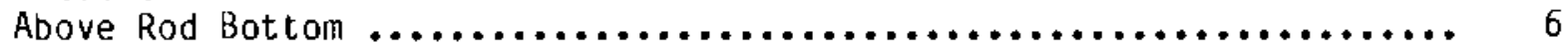

2. Reactor-Induced Hydride Breach in Sibling BWR Fuel Rod 123 ......... 7

3 Breaches in Fuel Rod 113 at Different Axial Locations Above Rod Bottom ........................................... 8

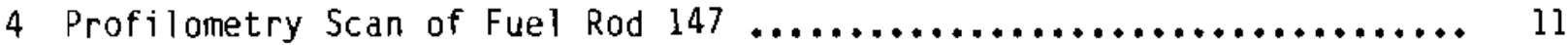

5 Profilometry Scan of Fuel Rod $113 \ldots \ldots \ldots \ldots \ldots \ldots \ldots \ldots \ldots, \ldots \ldots \ldots, 12$

6 Gamma Scan of Fuel Rod $147, \ldots \ldots \ldots \ldots \ldots \ldots \ldots \ldots \ldots \ldots \ldots \ldots \ldots, 13$

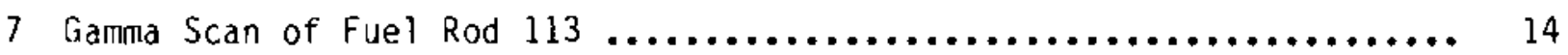

8 Experimental Setup for Fuel Rod Moisture Release Tests ............. 17

9 Axial Temperature Profile of the Furnace Tube $\ldots . . . \ldots \ldots \ldots . . . \ldots . .19$

10 Results of Moisture Release Test I with Fuel Rod $113 \ldots \ldots \ldots \ldots \ldots . . .24$

11 Results of Moisture Release Test II with Fuel Rod $113 \ldots \ldots \ldots \ldots \ldots . .26$

12 Results of Moisture Release Test II with Fuel Rod $147 \ldots \ldots \ldots \ldots \ldots . .27$

13 Results of Moisture Release Test III with Fuel Rod $147 \ldots \ldots . \ldots . \ldots . .28$

14 Results of Moisture Release Test IV with Fuel Rod $147 \ldots . . . \ldots . \ldots . .29$ 
1 Results of Fission Gas Collection from Intentionally Defected Fuel Rods ..................................... 15

2 Argon Cover Gas Analysis from Test I with $\operatorname{Rod} 113 \ldots \ldots . . \ldots \ldots . . . . . .24$

3 Analysis of Argon Cover Gas Samples from Fuel Rods 1937 and $512 \ldots \ldots$.... 30 


\section{INTROOUCTION}

Of the early light water reactor (LWR) fuel rods, being stored in spent fuel pools, up to $1 \%$ are believed to contain reactor-induced breaches. Some of the breached fuel has become water-logged due to exposure to the high-pressure reactor coolant and as a result of storage in the pools. While improvements in the fuel design, fuel manufacture, and reactor operating procedures have substantially reduced fuel failure in newer rods, older fuel rods, with low rates of decay heat, are prime candidates for dry storage. To determine fuel rod behavior in dry storage, a previous study conducted at the Battelle Columbus Division for the Commercial Spent Fuel Management (CSFM) Program Office(a) examined water-logged boiling water reactor (BWR) fuel rods containing reactorinduced cladding breaches (Kohli et al. 1985). The primary objective of that work was to investigate fuel oxidation in breached fuel rods on exposure to air and argon at high temperatures. During the course of that investigation, however, preliminary evidence showed that vacuum pumping at temperatures as low as $373 \mathrm{~K}$ resulted in significant moisture release from the breached fuel rods. These results suggested that the effects on the fuel and on the storage system components from the release of moisture to the dry storage atmosphere needed further definition.

Recently, Peehs and Fleisch (1986) described the behavior of water-logged pressurized water reactor (PWR) fuel rods on heating at $673 \mathrm{~K}$ in a hot cell. The bulk of the water ( 3 to $6 \mathrm{~g}$ per rod) was released during a simulated cask drying operation, with the temperature of release ( $673 \mathrm{~K})$ indicating that at least part of the water was bound chemically with the fuel. The presence of ${ }^{85} \mathrm{Kr}$ and tritium was also detected in the moisture released.

The prinary objective of the work discussed in the following text was to determine how much releasable water is contained in breached spent fuel rods, the amount of water released during an exposure to vacuum and temperature, and

(a) Work supported by U.S. Department of Energy, Office of Civilian Radioactive Waste Management through the Commercial Spent Fuel Management Division of the Richland 0perations office. The project was managed by the PNL Commercial Spent Fuel Management Program Office. 
the effects of the water on spent fuel rod integrity under dry storage conditions. The secondary objective was to determine the degree of water migration in a fuel rod and whether there are differences in this migration behavior between reactor-breached and intentionally defected rods and between $B W R$ and PWR fuel rods. The absorption and release of water in an intentionally defected rod could be significant in the event of a rod breach prior to cask loading or during wet consolidation because the presence of the water could result in fission gas release to the cask atmosphere during cask drying, as was observed by Peehs and Fleisch (1986). Furthermore, moisture could potentially react with Cs fission products to form a corrosive atmosphere for storage system seals, such as metal seals in a cask lid assembly.

To achieve the objectives, two well-characterized BWR fuel rods containing reactor-induced breaches and two intentionally defected fuel rods (one BWR and one PWR) were tested in the hot cell at a heating rate simulating the temperature rise in a storage cask during pump-down and dryout operations. Because the initial moisture content of the reactor-breached rods was unknown, a predetermined amount of moisture added to the intentionally defected rods enabled the extent of moisture release to be determined. The moisture release from the fuel rods was determined by weight changes monitored on a moisture absorbent. This report describes the results of the tests, along with pre-test characterizations and the test apparatus, specifications, and procedures. 


\section{CONCLUSIONS}

Based on the results of this limited series of tests, the following conclusions can be drawn:

1. The bulk of the uncombined moisture contained in water-logged, reactor-breached fuel rods was released within 3600 to 4800 s during heating in an axial temperature gradient $473 / 673 / 473 \mathrm{~K}$. The moisture was completely removed within $13,200 \mathrm{~s}$, regardless of the size of the breach, in agreement with recent results of another study (Peens and Fleisch 1986).

2. Water injected into the plenum of breached rods at $13.8 \mathrm{MPa}$ pressure to simulate reactor coolant system pressure is rapidly transported down the rod when heated and released through cladding breaches.

3. Axial migration of water in fuel rods occurs only if the fuel has previously been exposed to reactor coolant, i.e., breached fuel rods. In intentionally defected fuel rods, water added to the rod tends to be absorbed by the fuel and moisture does not migrate axially.

4. In intentionally defected fuel rods, some fission gas is released from the fuel on heating in the presence of water. 
.

. 


\section{PRE-TEST CHARACTERIZATION OF FUEL RODS}

Two fuel rods with reactor-breached cladding (BWR) and two intentionally defected fuel rods (one each BWR and PWR) were characterized before the experiments began.

\section{REACTOR-BREACHED FUEL RODS}

The two reactor-breached BWR fuel rods were extensively characterized prior to testing. Rod 147 taken from a $7 \times 7$ assembly with an average burnup of $22.4 \mathrm{MWd} / \mathrm{kgU}$ was nominally $1.44 \mathrm{~cm}$ in diameter. Rod 113 taken from an $8 \times 8$ assembly with an average burnup of $15.6 \mathrm{MWd} / \mathrm{kgU}$ was nominally $1.28 \mathrm{~cm}$ in diameter. The rods were in pool storage for about $4 \mathrm{yr}$ before they were shipped dry to the Battelle Hot Cell Laboratory in West Jefferson, Ohio. There, they were stored dry and open to flowing air atmosphere in the hot cell at an average cell temperature of $296 \mathrm{~K}$ for approximately 4-3/4 yr prior to examination and testing.

Visual examination with a stereo-optical viewing system revealed that both fuel rods contained large reactor-induced cladding breaches. Rod 147 had a large hole approximately $4 \mathrm{~cm}$ from the bottom end (Figure 1a) and two long cracks at 229 and $244 \mathrm{~cm}$ from the bottom (Figure 1b and 1c). By metallographic examination of sibling rods, these cracks were identified as secondary hydride breaches (Figure 2). Rod 113, on the other hand, showed two large open holes at approximately 89 and $92 \mathrm{~cm}$ from the bottom through which the fuel was visible (Figure $3 a$ and $3 b$ ). In addition, a significant buige (not a through-wall crack according to eddy current tests) was observed at approximately $246 \mathrm{~cm}$ from the bottom (Figure $3 \mathrm{~d}$ ), which is assumed to be the start of a secondary breach. A continuous videotape recording was made of the surface features of each rod along the entire length. The fuel rod identification numbers were used as the 0 degrees azimuthal reference orientation marks. To cover the entire surface, each rod was videotaped from bottom to top at 120-degree azimuthal intervals by rotating in a clockwise direction looking at the bottom of each rod. 


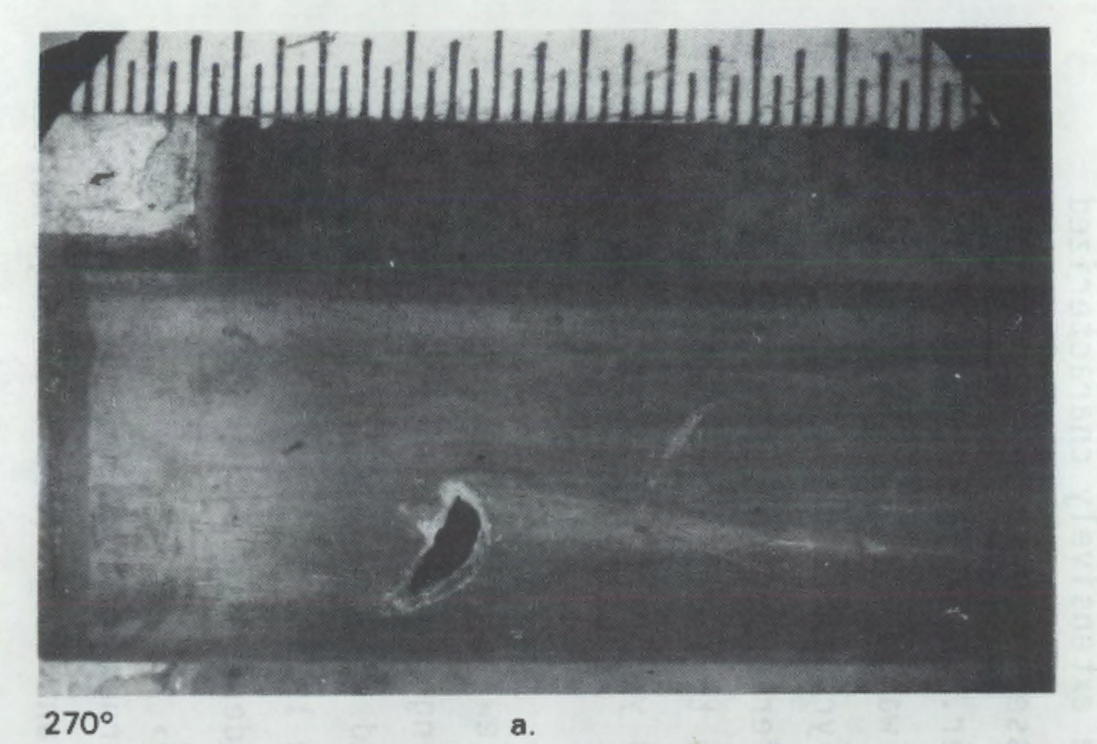

a

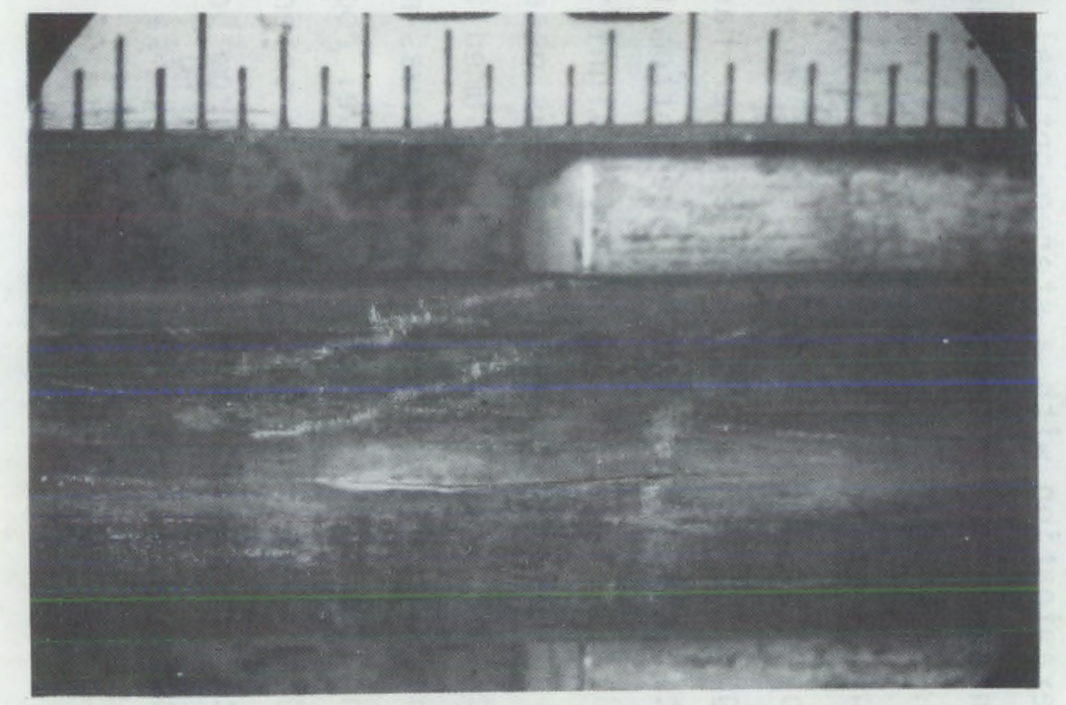

$90^{\circ}$ b.

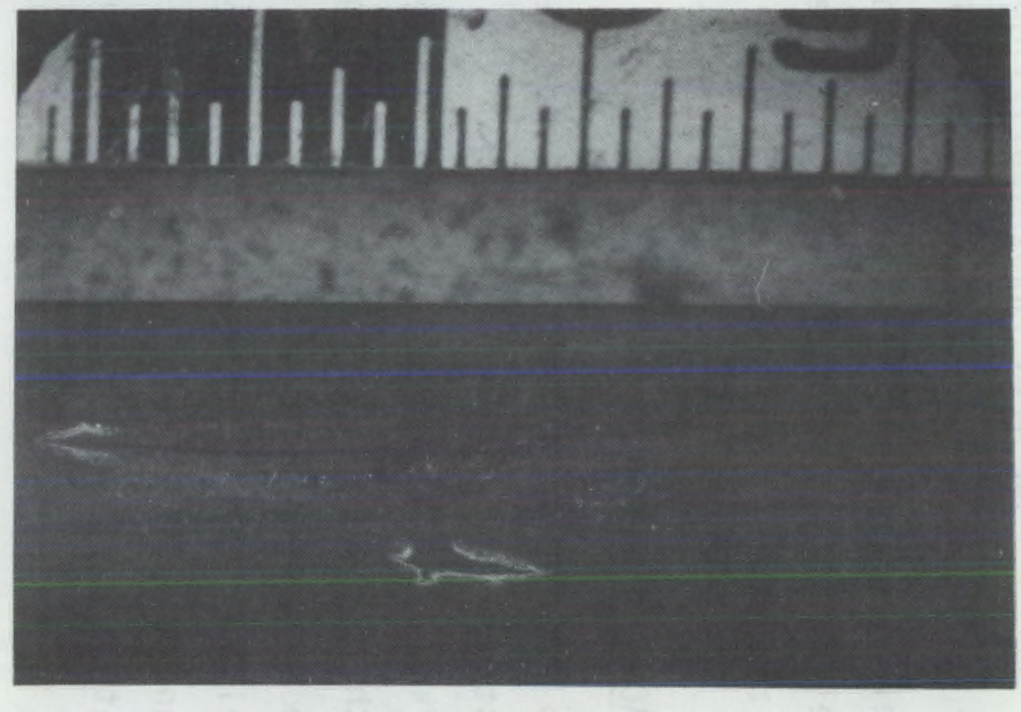

$90^{\circ}$ c.

FIGURE 1. Breaches in Fuel Rod 147 at Different Axial Locations Above Rod Bottom; a. $4 \mathrm{~cm}$, b. $229 \mathrm{~cm}$, c. $244 \mathrm{~cm}$. 

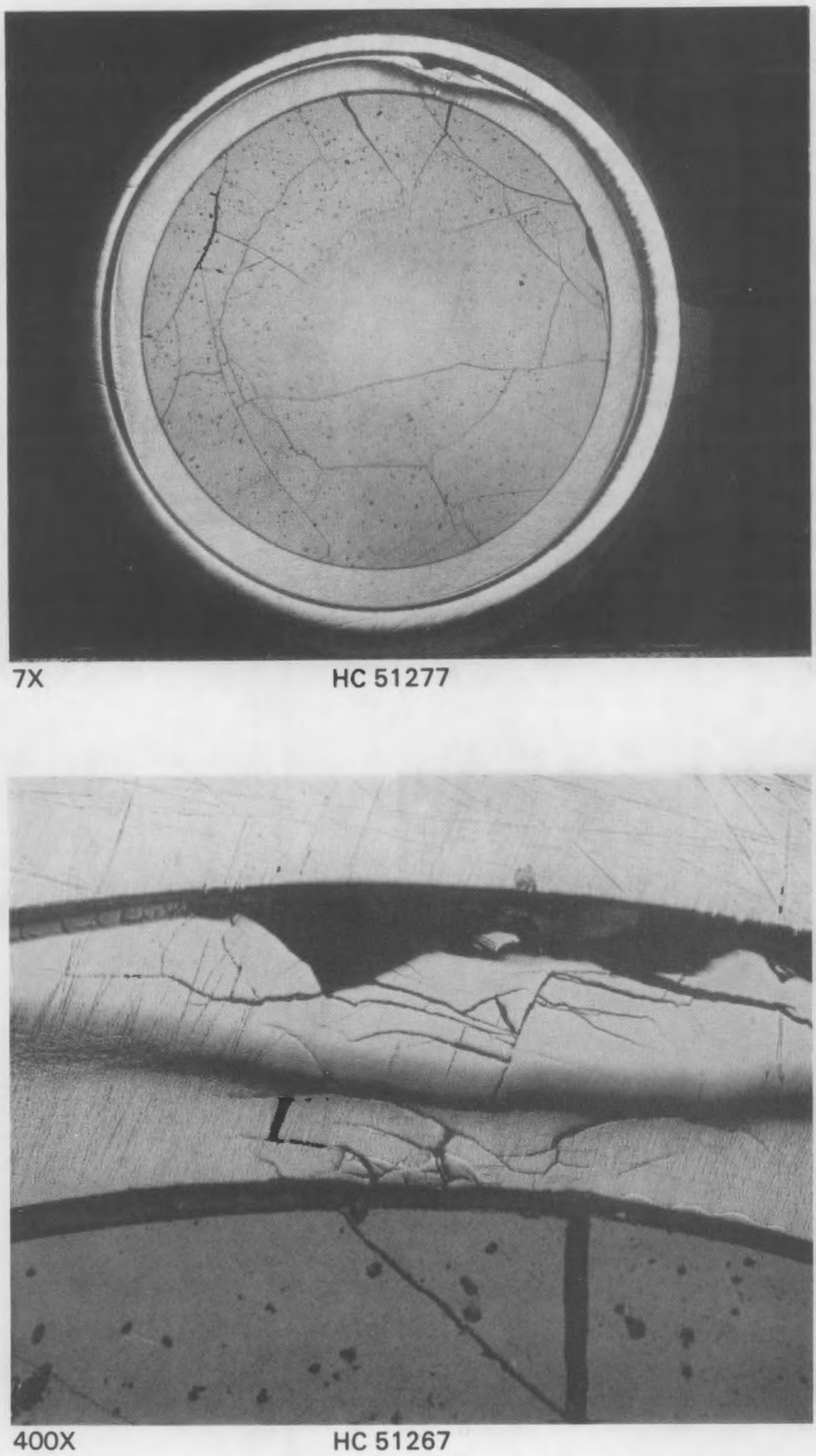

FIGURE 2. Reactor-Induced Hydride Breach in Sibling BWR Fuel Rod 123 

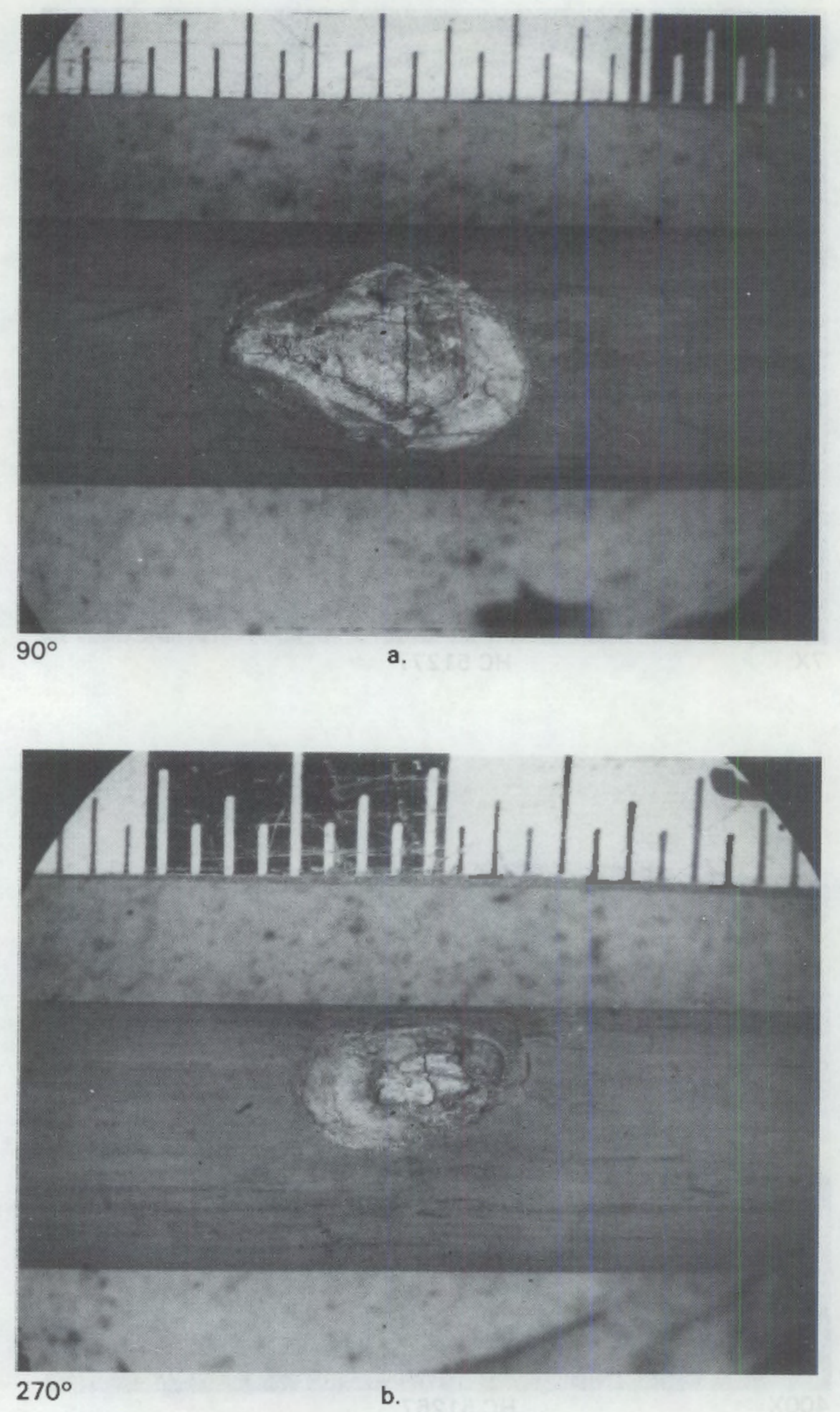

FIGURE 3. Defects in Fuel Rod 113 at Different Axial Locations Above Rod Bottom; a. $89 \mathrm{~cm}$, b. $92 \mathrm{~cm}$, c. 89 and $92 \mathrm{~cm}, \mathrm{~d} .246 \mathrm{~cm}$. 

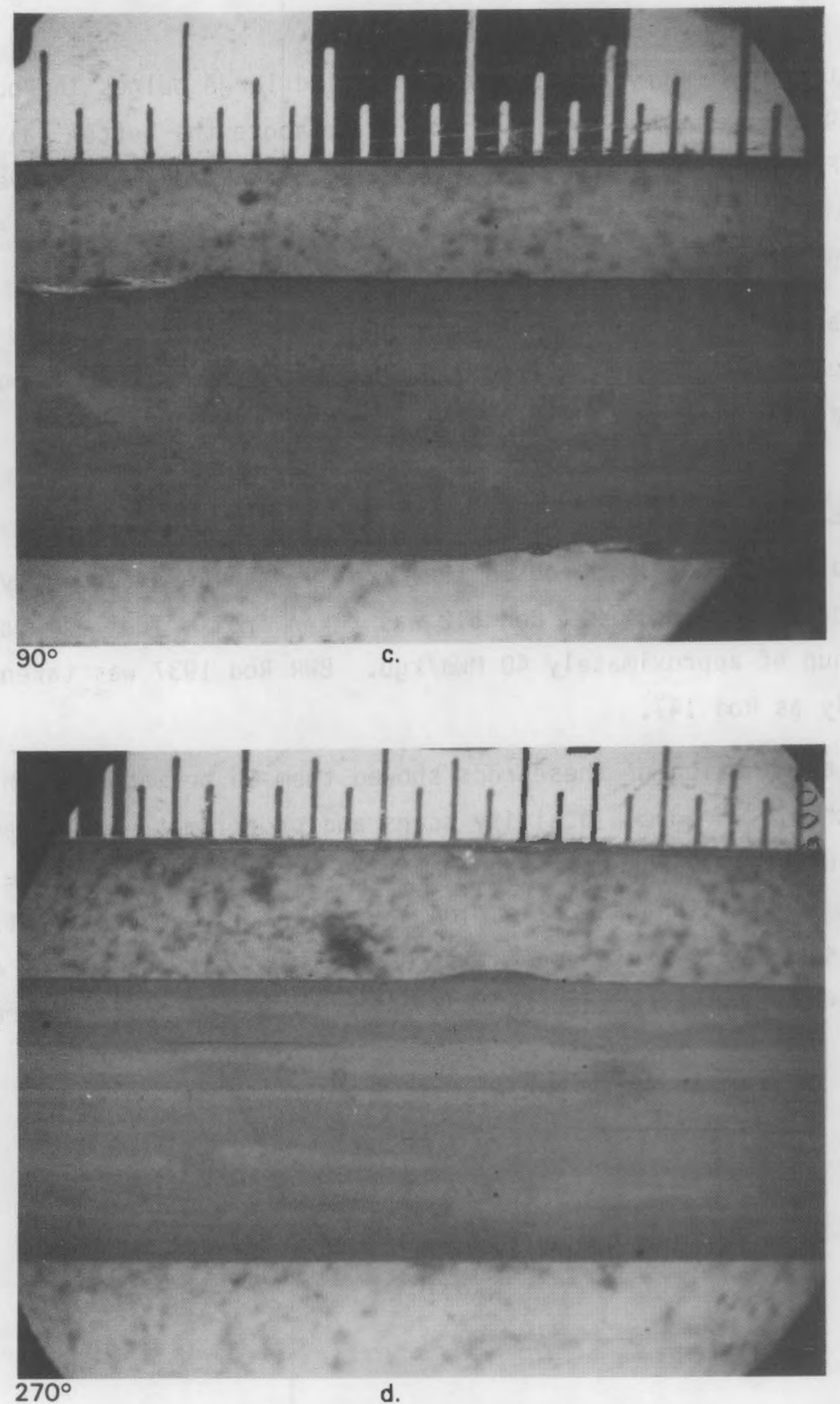

FIGURE 3. (contd) 
Pretest profilometry measurements revealed large bulges in Rod 147 at 229 , 244, and $249 \mathrm{~cm}$ and a smaller bulge at $190 \mathrm{~cm}$ above the bottom, as shown in Figure 4. For Rod 113, the profilometry measurements revealed several large bulges from 58 to $104 \mathrm{~cm}$ above the bottom. Other large bulges were evident at $116,150,193,204,246$, and $249 \mathrm{~cm}$ above the bottom (Figure 5).

Gamma activity was scanned on both fuel rods. Some fuel loss was observed from the breached locations at 241 to $246 \mathrm{~cm}$ and $89 \mathrm{~cm}$ above the bottom of Rods 147 and 113, respectively (Figures 6 and 7).

\section{INTENTIONALLY DEFECTED FUEL ROOS}

The two intentionally defected fuel rods were also extensively characterized prior to testing. PWR Rod 512 was taken from a fuel assembly with an average burnup of approximately $40 \mathrm{MWd} / \mathrm{kgU}$. BWR Rod 1937 was taken from the same assembly as Rod 147.

Visual examination of these rods showed them to be intact with no evidence of any breaches. The gamma activity scans and profilometry measurements revealed no unusual features or abnomalities. Both fuel rods were punctured (1-mm holes) for fission gas collection and void volume measurements. As shown in Table 1, substantial volumes of fission gas were collected from each rod, providing further evidence that these fuel rods were not reactor-breached. 


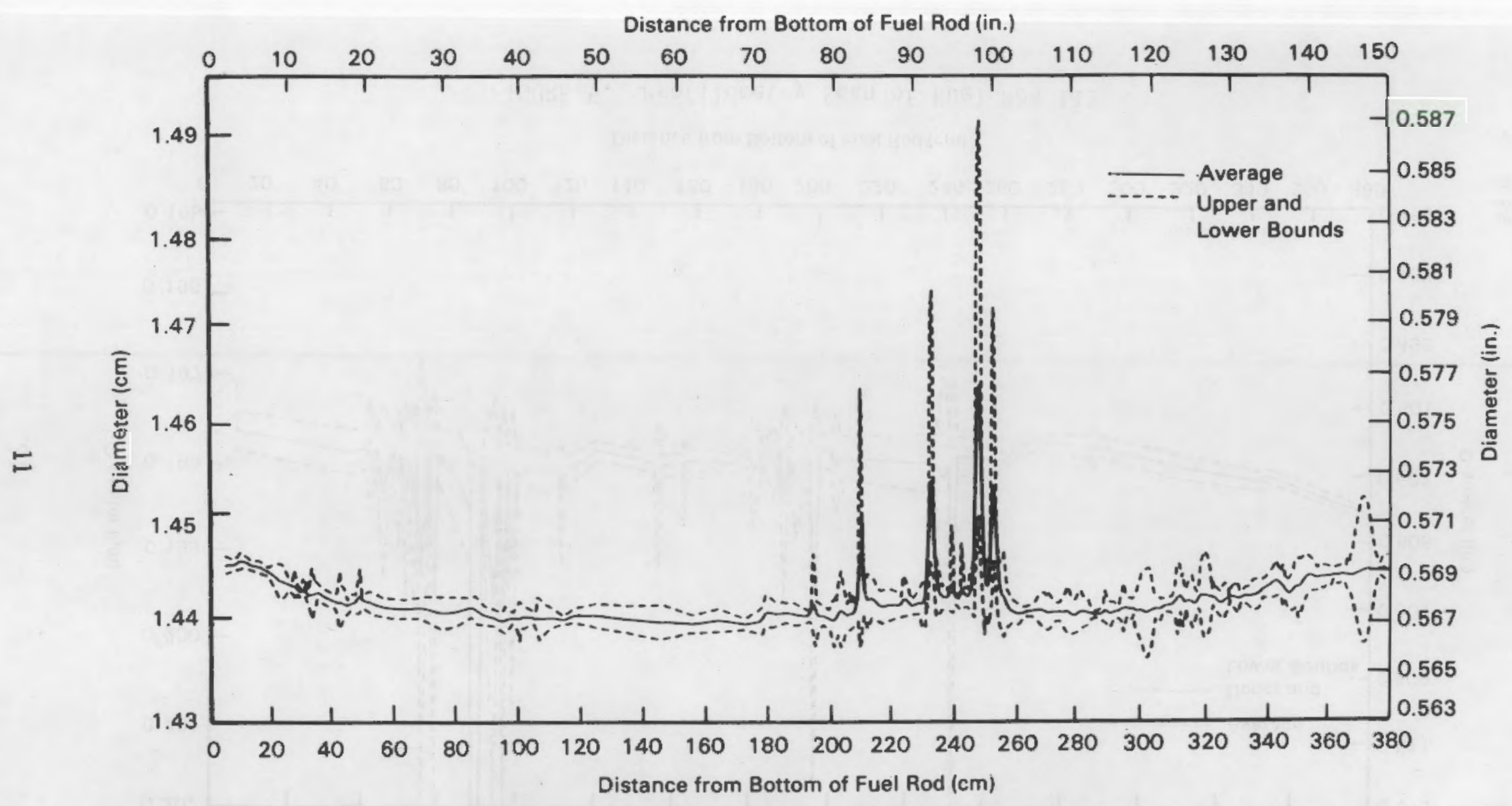

FIGURE 4. Profilometry Scan of Fuel Rod 147 
Distance From Bottom of Fuel Rod (in.)

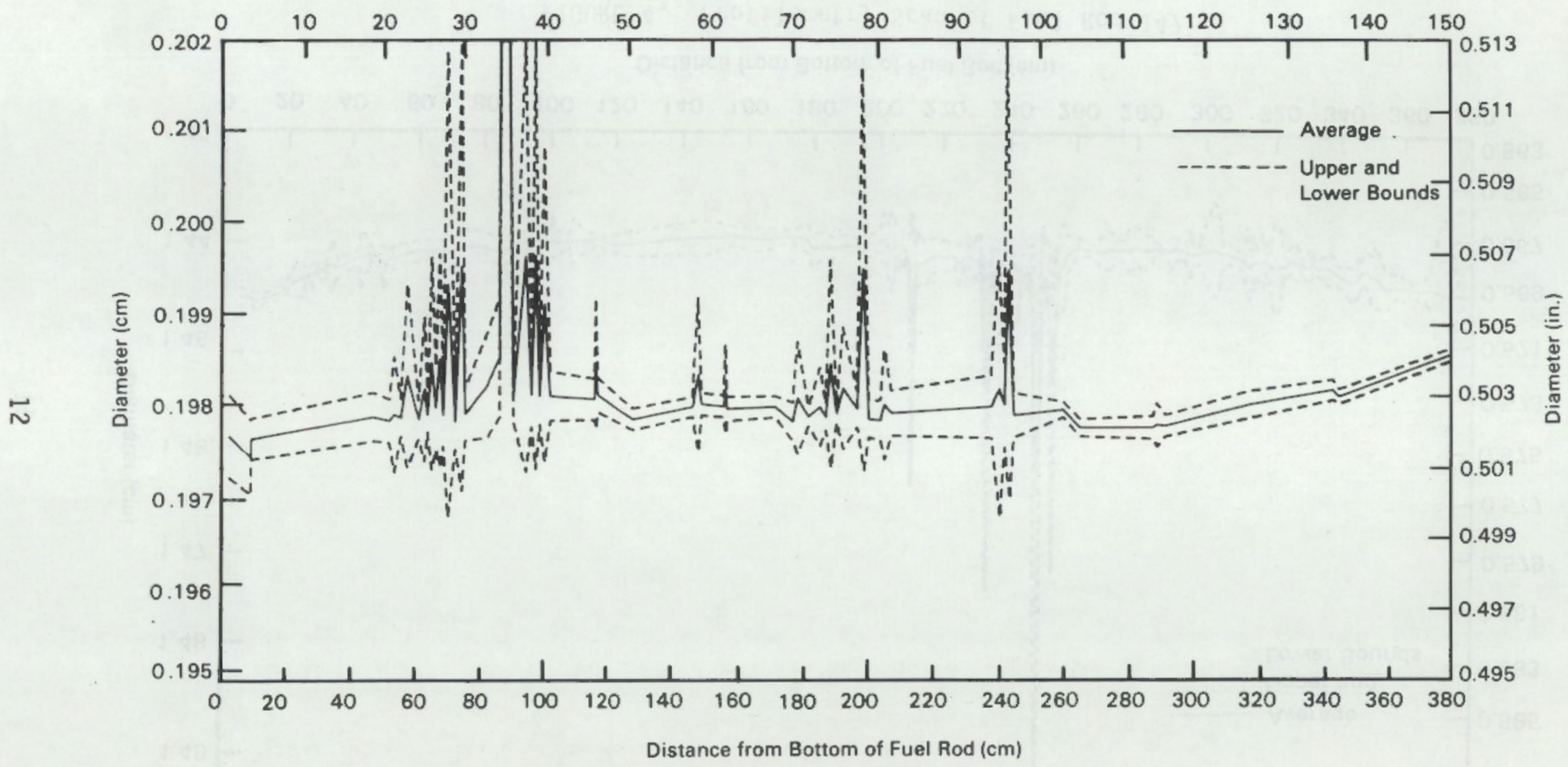

FIGURE 5. Profilometry Scan of Fuel Rod 113 


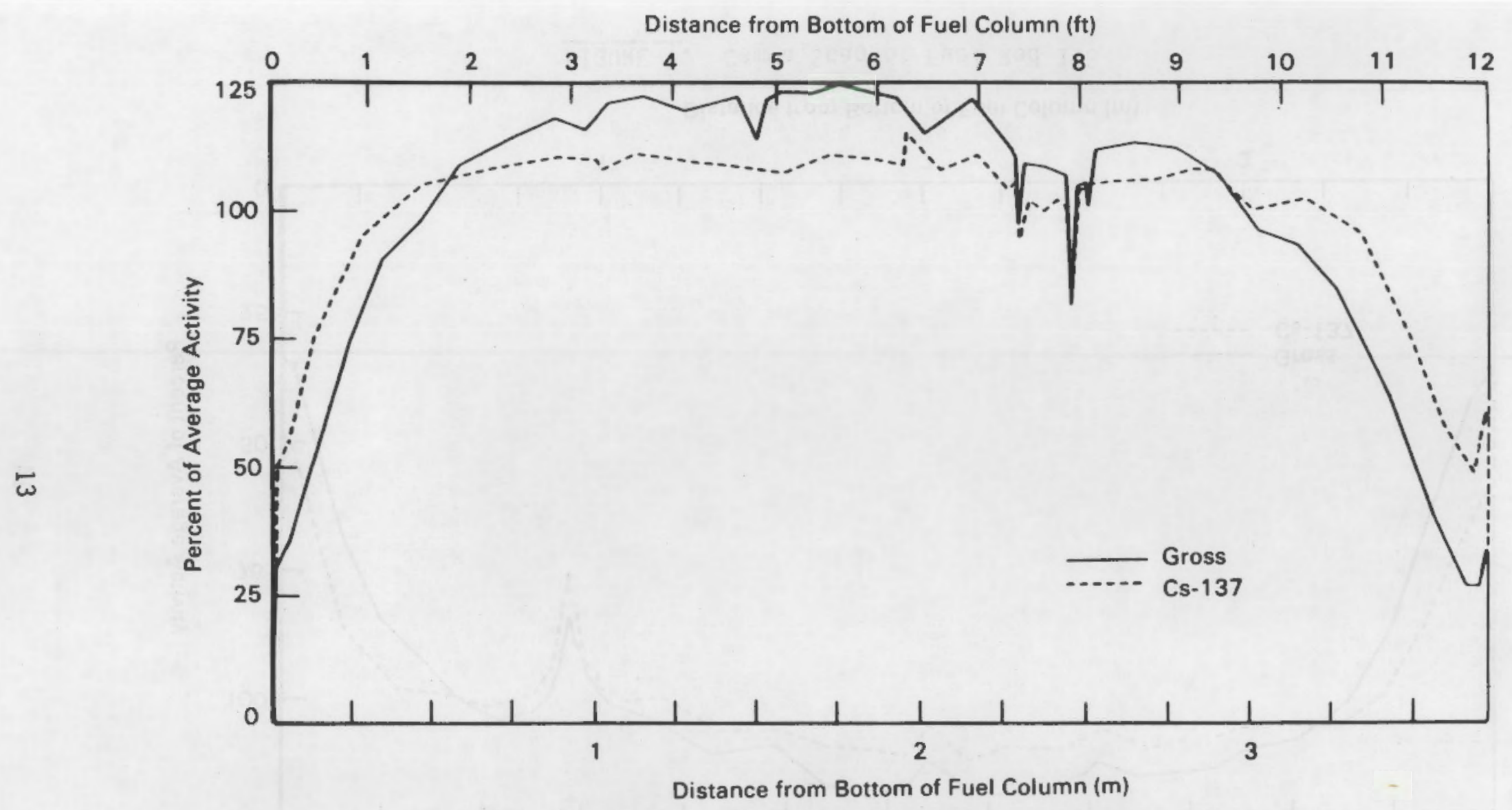

FIGURE 6. Gamma Scan of Fuel Rod 147 


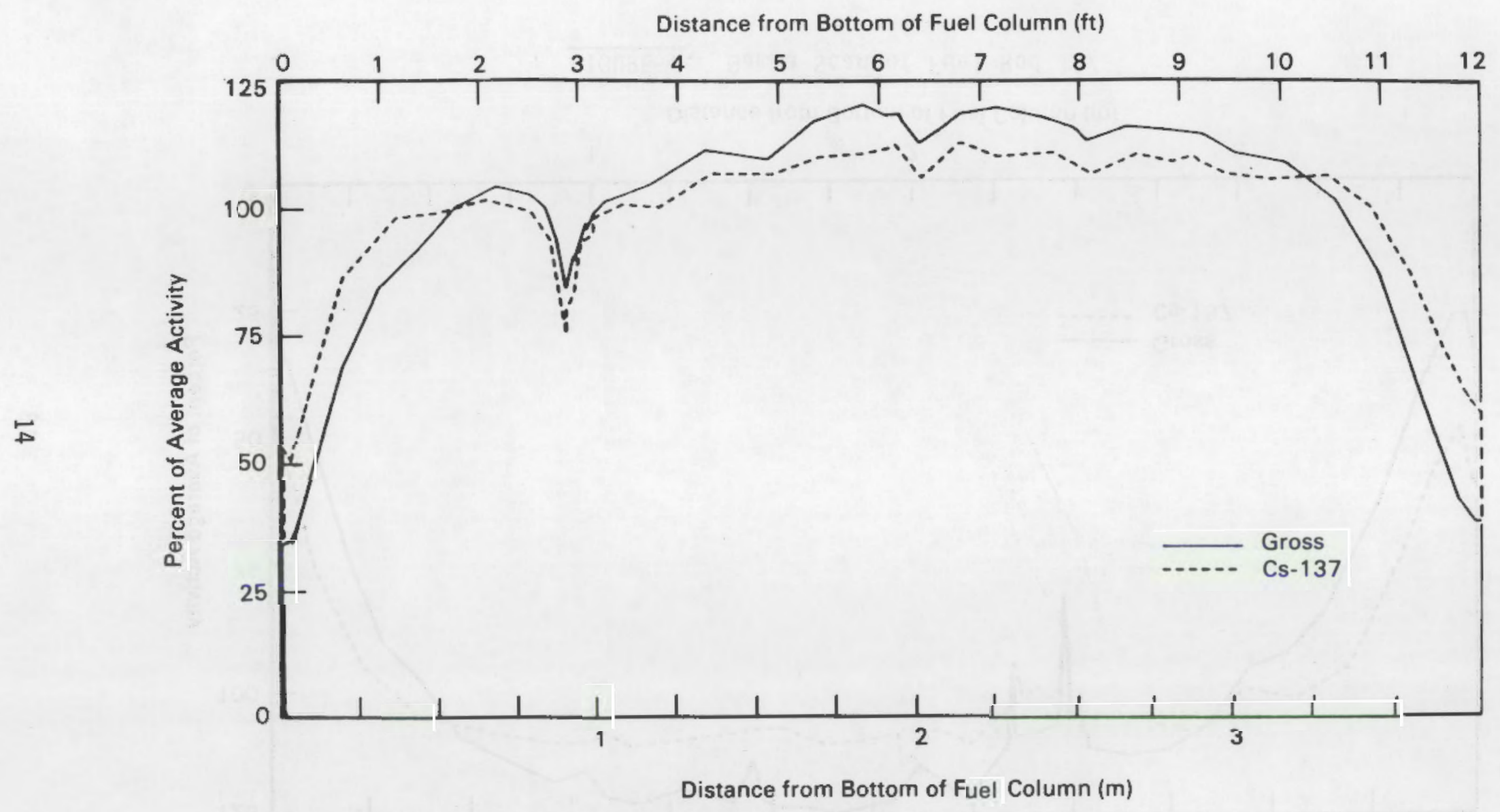

FIGURE 7. Gamma Scan of Fuel Rod 113 
TABLE 1. Results of Fission Gas Collection from Intentionally Defected Fuel Rods

\begin{tabular}{|c|c|c|c|c|c|}
\hline $\begin{array}{l}\text { Rod } \\
\text { No. }\end{array}$ & $\begin{array}{l}\text { Fuel } \\
\text { Rod } \\
\text { Type } \\
\end{array}$ & $\begin{array}{l}\text { Total Gas } \\
\text { Collected, } \\
\mathrm{cm}^{3} \text { STP }\end{array}$ & $\begin{array}{l}\text { Plenum } \\
\text { Volume, } \\
\mathrm{cm}^{3}\end{array}$ & $\begin{array}{c}\begin{array}{c}\text { Internal } \\
\text { Void } V_{\text {glume, }} \\
\mathrm{cm}^{3}\end{array} \\
\end{array}$ & $\begin{array}{c}\text { Percent } \\
\text { Fission Gas } \\
\text { Released } \\
\end{array}$ \\
\hline $\begin{array}{r}512 \\
1937\end{array}$ & $\begin{array}{l}\text { PWR } \\
\text { BWR }\end{array}$ & $\begin{array}{l}550 \\
517\end{array}$ & $\begin{array}{r}8 \\
18\end{array}$ & $\begin{array}{l}14 \\
57\end{array}$ & $\begin{array}{l}0.5 \\
21\end{array}$ \\
\hline
\end{tabular}




\section{TEST DESIGN}

This section describes the apparatus developed for the tests both inside and outside the hot cell, the test specifications, and the general procedure for the experiments.

\section{APPARATUS}

The equipment illustrated in Figure 8 was designed and fabricated for this study to simulate dry storage conditions and to measure subsequent moisture release from the fuel rods. It consists of a two-zone, stainless steel furnace tube (Zone M, $\sim 120 \mathrm{~cm}$ long; Zone $\mathrm{N}, \sim 180 \mathrm{~cm}$ long) containing three collars to support the fuel rod during the test. The furnace tube is connected to the gas

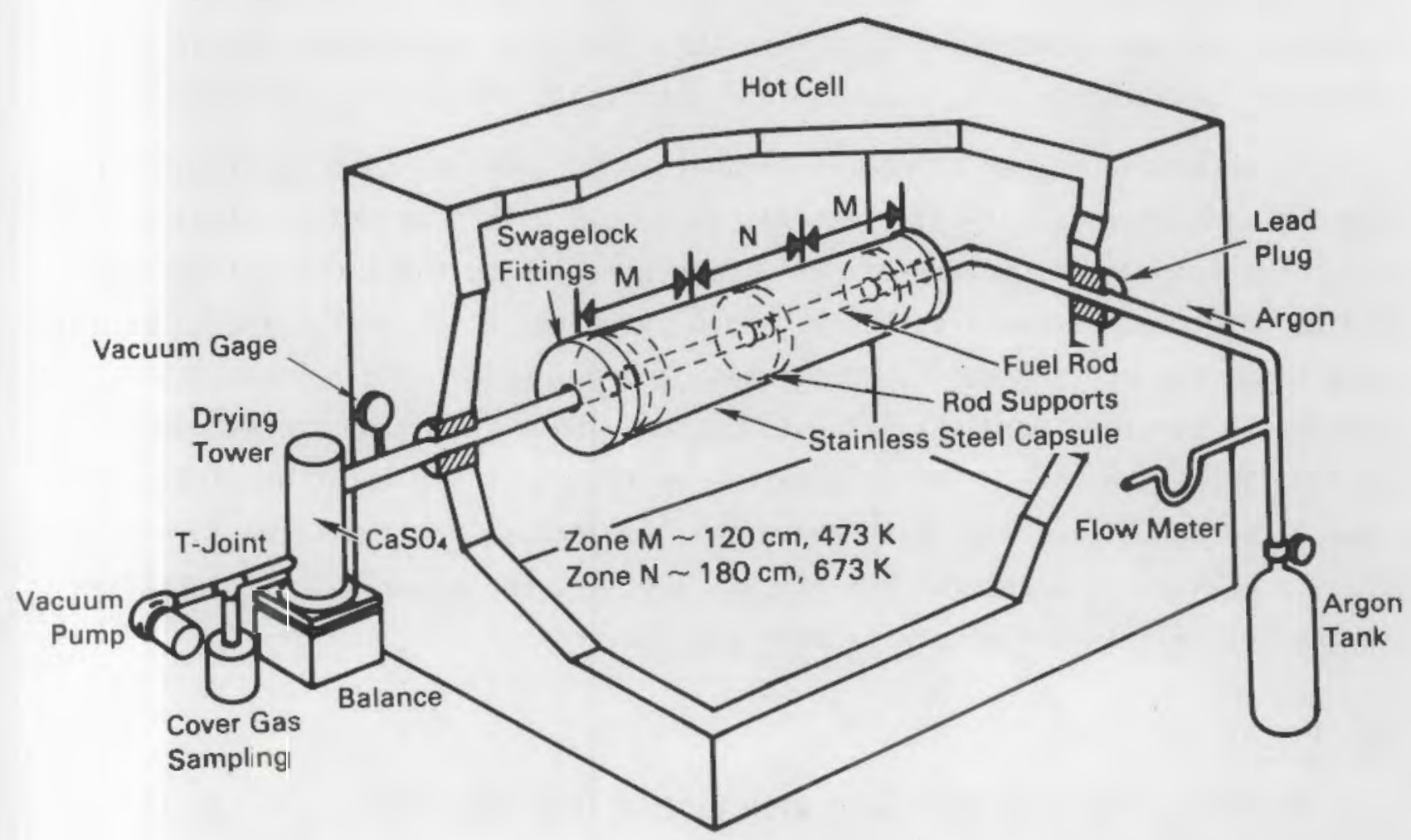

FIGURE 8. Experimental Setup for Fuel Rod Moisture Release Tests 
inlet, drying, and gas collection system with pressure-tight Swagelok@(a) fittings. An argon cover gas flow was used to ensure that all moisture released from the fuel rod was carried out of the hot cell into the drying tower, which initially contained calcium chloride. Later, calcium sulfate was used in place of calcium chloride to reduce the degradation of the drying tower caused by the exothermic reaction.

The apparatus was designed to simulate axial temperature gradients in a storage cask. The temperature of the center $180 \mathrm{~cm}$ of the fuel rod (Zone $\mathrm{N}$ ) was raised from $298 \mathrm{~K}$ to approximately $673 \mathrm{~K}$ at a heating rate of approximately $100 \mathrm{~K} / \mathrm{h}$ under vacuum pumping to simulate the temperature rise in a storage cask during pump-down and dryout operations. The temperature at either end of the rod (Zone M, approximately $120 \mathrm{~cm}$ long) was maintained at $473 \mathrm{~K}$ during the test. The test temperature was maintained until no further moisture release was observed, as indicated by a weight change of $\pm 0.01 \mathrm{~g}$ of the desiccant. The temperatures were controlled to within 10K. The test atmosphere was argon, which was analyzed to determine whether detectable fission gas was released.

To determine the experimental parameters for in-cell testing of the fuel rods, a simulated out-of-cell test was conducted with a stainless steel solid rod. The purpose of the out-of-cell experiment was to check out all systems and to determine parameters such as argon cover gas flow rates, time to achieve test temperature, temperature ramp rates, and pump-down rate. In addition, the furnace temperature gradient was established with a series of thermocouples located along the tube. The temperature variation at any location within Zone $\mathrm{N}$ did not exceed $\pm 10 \mathrm{~K}$ with the axial temperature profile shown in Figure 9. Following successful out-of-cell testing, the apparatus was installed in the hot cell to perform tests with the fuel rods.

\section{SPECIFICATIONS}

Several tests were performed with each of the fuel rods. The specifications for each test are given below.

(a) Crawford Fitting Company, Solon, Ohio.

(a) Use of trade name does not imply PNL endorsement. 


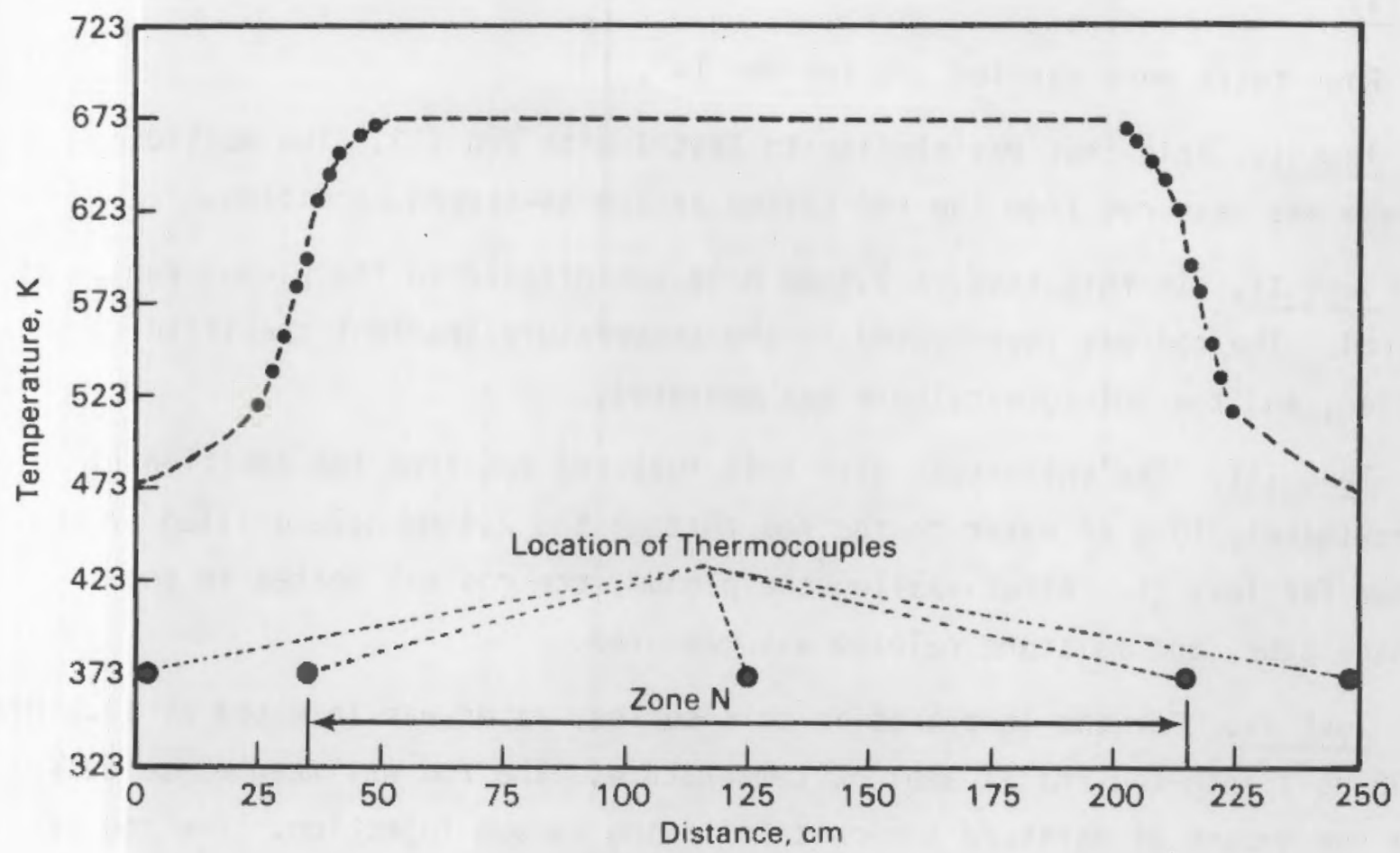

FIGURE 9. Axial Temperature Profile of the Furnace Tube

$\underline{\operatorname{Rod} 113}$

Three tests were designed for Rod 113.

Test 1. The rod was tested in the as-stored condition. The moisture contained in the rod was measured by heating the rod in the specified temperature gradient.

Test II. In this test, approximately $10 \mathrm{~g}$ of water were added to the fuel rod through a 2.4-rmm hole drilled in the plenum. The plenum was then sealed, and the moisture release was measured in the $473 / 673 / 473 \mathrm{~K}$ gradient.

Test III. Depending on Test II, if water was not recovered from the plenum, a 2.4-mm hole would be drilled in the cladding approximately 300 to $330 \mathrm{~cm}$ from rod bottom. The rod would then be heated in a $473 / 673 / 473 \mathrm{~K}$ gradient, and the moisture release measured. 
Rod 147

Four tests were carried out for Rod 147.

Test I. This test was similar to Test I with Rod 113. The moisture release was measured from the rod tested in the as-stored condition.

Test II. In this test, a 2.4-mm hole was drilled in the plenum region of the rod. The rod was then heated in the temperature gradient specified earlier, and the moisture release was measured.

Test III. The third test with this fuel rod required the addition of approximately $10 \mathrm{~g}$ of water to the rod through the 2.4-mm hole drilled in the plenum for Test II. After sealing the plenum, the rod was heated in the furnace tube, and moisture release was measured.

Test IV. For the last test in this series, water was injected at $13.8 \mathrm{MPa}$ (2000 psi) into the rod at ambient temperature. The rod was weighed to determine the amount of moisture absorbed following vacuum injection. The rod was then heated in the furnace tube, and the moisture release was measured. Rod 1937

Only one test was performed with BWR Rod 1937. Approximately $10 \mathrm{~g}$ of water were added to the rod through a 2.4-mm hole drilled in the plenum region, and the plenum was sealed. A second hole, approximately 2.4-mm in diameter, was drilled in the cladding between the ends of the seventh and eighth fuel pellets from the bottom of the rod $(\sim 9 \mathrm{~cm})$. The rod was then heated in the specified temperature gradient, and the moisture release was measured. Rod 512

One test was also conducted with PWR Rod 512. The specifications for this test were identical to those for BWR Rod 1937. The plenum was injected with water $(10 \mathrm{~g})$ and sealed. The second 2.4-mm hole was drilled at approximately $11 \mathrm{~cm}$ from the bottom of the rod (between the seventh and eighth fuel pellets). The rod was heated in the furnace tube, and the moisture release was measured. 


\section{PROCEDURE}

The general procedure for all tests was to prepare each fuel rod for the specific experiment prior to loading into the furnace tube. This preparation involved (as required) drilling the cladding holes with a center drill; water addition to the rod using a syringe; high-pressure water injection of the fuel rod placed in an evacuated tube; and rod weighing using a digital balance or a load cell.

Following preparation, the rod was loaded into the furnace capsule, and the power and vacuum and argon gas flow lines were connected. The fuel rod was heated at the predetermined rate $(100 \mathrm{~K} / \mathrm{h})$ while evacuating the furnace tube to simulate cask dryout conditions. The amount of moisture released during this heating period was noted by recording the weight change of the desiccant at $240-s$ intervals. When the temperature of Zone $\mathrm{N}$ reached the maximum of $673 \mathrm{~K}$, the vacuum line was closed and the argon gas flow was started. Samples of the argon cover gas were obtained to determine the presence of detectable fission gas. Further moisture release was noted from the weight change of the desiccant.

The experiment was discontinued when no further weight change $( \pm 0.01 \mathrm{~g})$ was observed in the desiccant. Once the experiment was completed, the fuel rod was removed and reweighed, if necessary, or it was prepared for the next test. 
RESULTS AND DISCUSSION

The out-of-cell tests showed that the in-cell portion of the apparatus would successfully simulate dry storage conditions during cask dryout. This section gives the results obtained from experiments conducted within the hot cell.

ROD 113

Only two of the tests were required for Rod 113.

Test I

The first experiment was performed with Rod 113 taken directly from storage. The rod was loaded into the furnace capsule, and the electrical power and vacuum and argon gas flow lines were connected. The results of this experiment are graphically illustrated in Figure 10, where time, temperature, pressure, and weight gain data for the test are recorded. As can be seen, the bulk of the moisture was released from the fuel rod in the first $1800 \mathrm{~s}$ after startup, at a temperature of approximately 373K. No further moisture release was measurable, as the temperature was raised to a maximum of $723 \mathrm{~K}$ and then maintained at $653 \mathrm{~K}$ for $120 \mathrm{s.}$ (a) Argon cover gas samples were obtained at the times indicated in Figure 10 and analyzed. The results of analysis (Table 2) showed the complete absence of detectable fission gas xenon or krypton. This result is in contrast to the results reported by Peehs and Fleisch (1986) in which both ${ }^{85} \mathrm{Kr}$ and tritium were released during testing of two water-logged PWR fuel rods. Also, very little moisture was found in the present test, suggesting that the rod contained almost no moisture to begin with. This assumption was confirmed by inspecting the weight gain data; the total quantity of moisture released from Rod 113 was only $0.8 \mathrm{~g}$.

(a) This test was performed in a two-step Zone $N$ heating mode to simulate cask drying operations (Zone $M$ was maintained at $373 \mathrm{~K}$ ). However, since the bulk of the moisture was removed at a temperature of $373 \mathrm{~K}$, all subsequent tests were conducted in a single heating mode (Zone $\mathrm{N}=673 \mathrm{~K}$; Zone $\mathrm{M}=$ $473 K)$. 


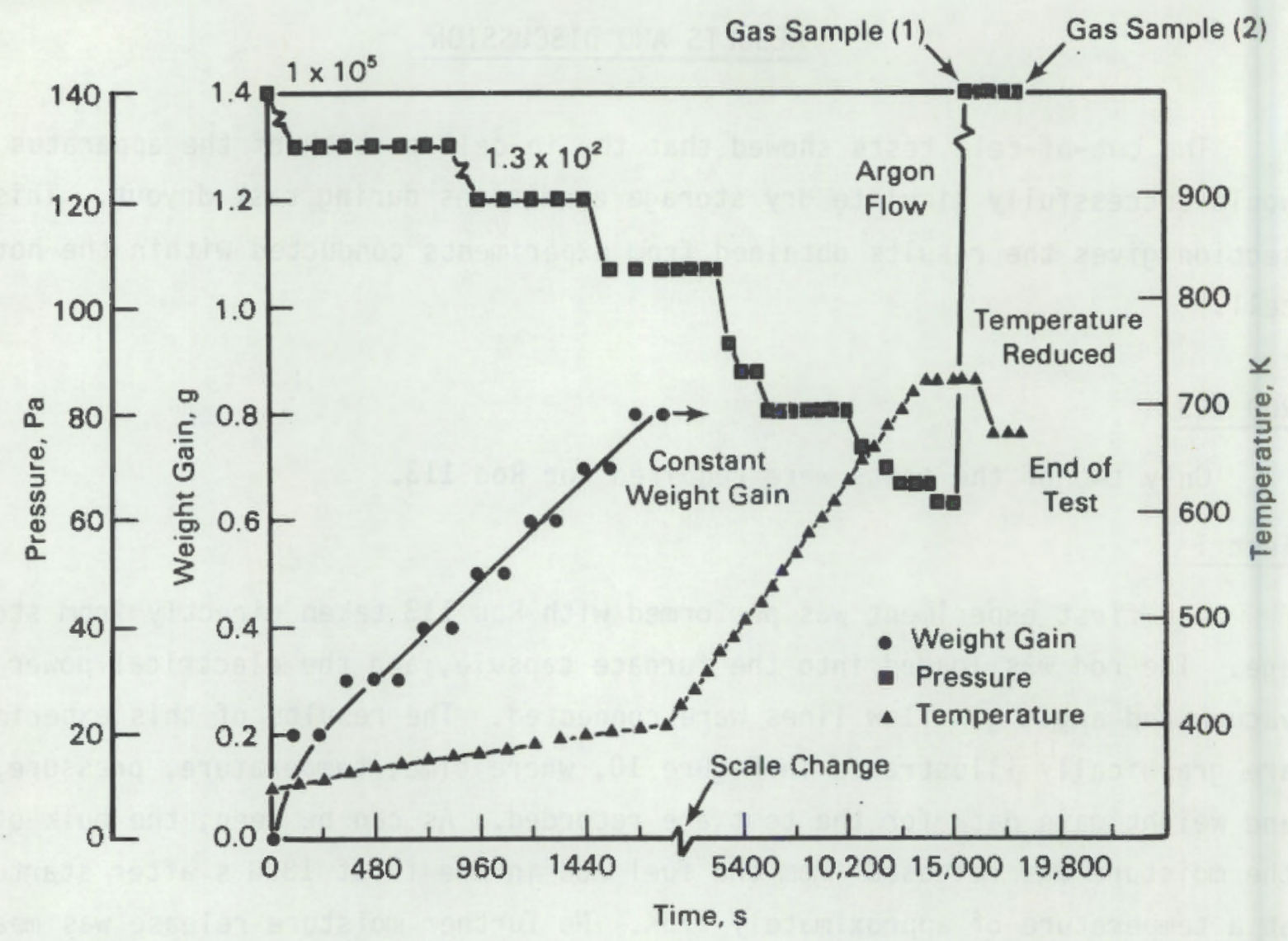

FIGURE 10. Results of Moisture Release Test I with Fuel Rod 113

TABLE 2. Argon Cover Gas Analysis from Test I with Rod 113

\begin{tabular}{|c|c|c|c|c|c|c|c|c|c|}
\hline Gas Sample & $\mathrm{He}$ & $\mathrm{N}_{2}$ & & $\bar{A}$ & $\mathrm{H}_{2}$ & $\mathrm{CO}_{2}$ & $\mathrm{H}_{2} \mathrm{O}$ & $\underline{\mathrm{Xe}}$ & $\mathrm{Kr}$ \\
\hline 1 & $N D^{(a)}$ & $56.56^{(a)}$ & $15.77^{(b)}$ & 26.53 & 0.20 & 0.20 & 0.72 & ND & ND \\
\hline 2 & ND & 0.43 & 0.19 & 99.16 & 0.22 & ND & 0.09 & ND & ND \\
\hline
\end{tabular}

(a) $N D=$ Not detected; detection limit $=0.0001 \%$.

(b) These high values for oxygen and nitrogen are probably due to inleakage of air in the gas collection system; otherwise, significant fuel oxidation would have occurred in the rod. 
Because the internal void volume of the rod was $57 \mathrm{~cm}^{3}$ (based on sibling Rod 1937 measurement), three possible reasons for the low moisture release from the rod were considered: 1) The test conditions did not provide sufficient driving force to release the moisture trapped in the void spaces in the fuel colurin. This would be particularly true if the water were combined chemically (U-0-H, Cs-0-H compounds) rather than physically (pores, surface adhesion) in the fuel. These tests do not lend themselves to detection of water tightly bound to the fuel. 2) The rod had been stored in an open tube and exposed to the flowing air atmosphere in the hot cell for approximately 4-3/4 yr (since 1979) prior to testing; consequently, additional drying could have occurred, aided by air flow through the cell. 3) More importantly, as shown previously (Kohli et al. 1985), vacuum pumping alone does not provide sufficient driving force to remove the moisture contained in the plenum of reactor-breached BWR rods. Less than $30 \%$ of the moisture in these rods was released through large, open breaches located sufficiently distant $(\sim 175 \mathrm{~cm})$ from the plenum. Significant quantities of additional moisture were then removed from the rods after drilling a hole in the plenum and vacuum pumping at 375 to $403 \mathrm{~K}$. The results of these tests with sibling rods indicated that the bulk of the moisture in Rod 113 could also be present in the plenum. Because the plenum was maintained at approximately $373 \mathrm{~K}$ in the present test, there was sufficient thermal driving force to release moisture had a reactor breach been present in the plenum.

To test the third hypothesis, a 2.4-min hole was drilled in the plenum and the test was repeated. No further moisture was released, however, lending credence to the second hypothesis of rod dryout due to long storage in the hot cell. Test II

Using a syringe, approximately $10 \mathrm{~cm}^{3}$ of water were added to the plenum through the fission gas punch hole. The hole was then sealed with a Swagelok connector. The rod was loaded into the test chamber, and the experiment was started. The results are shown in Figure 11, which gives time, temperature, pressure, and weight change data. About $75 \%$ of the added water was released within a test period of $3600 \mathrm{~s}$ while the temperature was increased to approximately $400 \mathrm{~K}$. The remaining moisture was released at a much slower rate, 


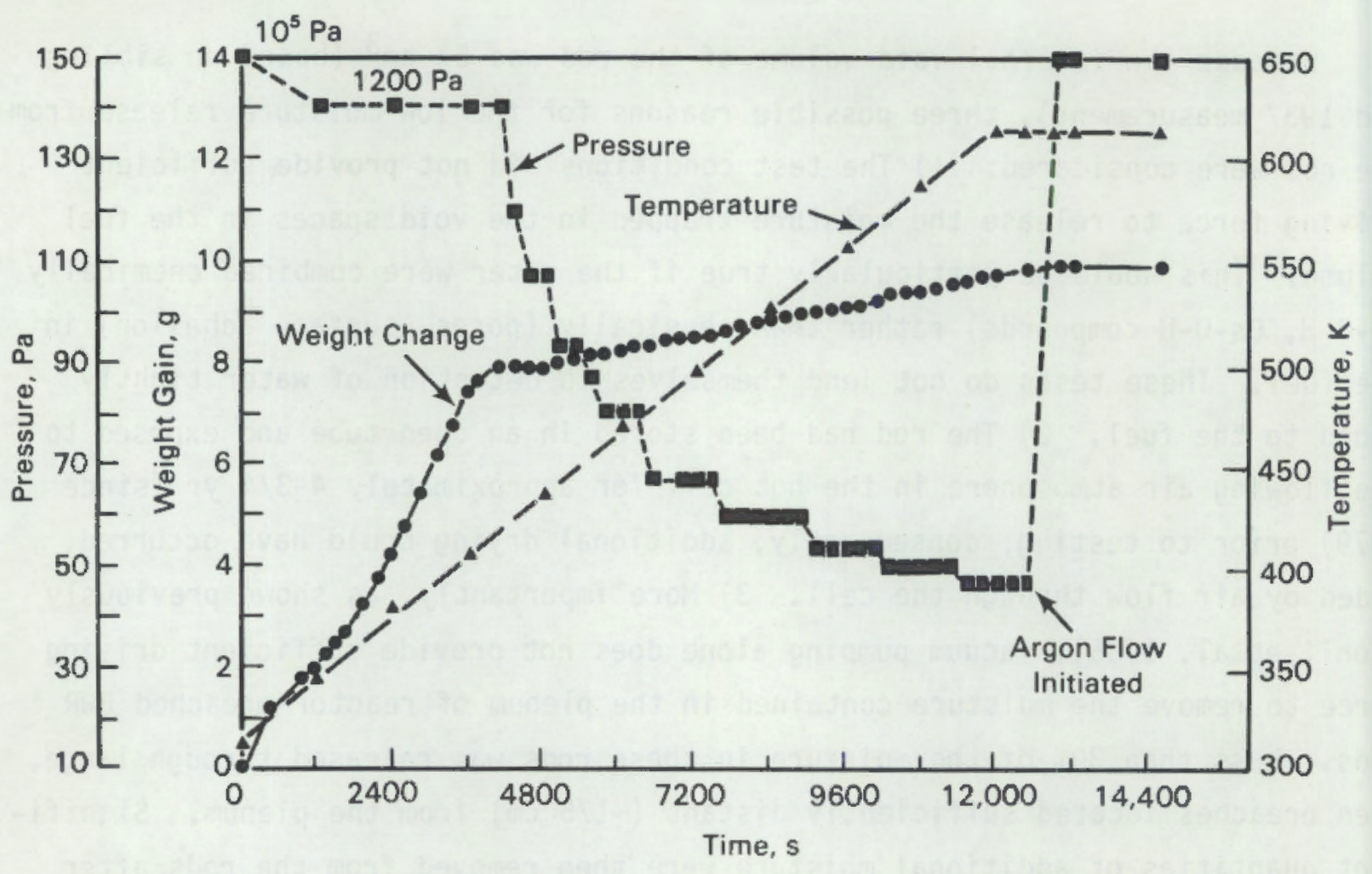

FIGURE 11. Results of Moisture Release Test II with Fuel Rod 113

although the temperature was raised to 673K. Apparently, all of the moisture was released even before the argon gas flow was started; $10 \mathrm{~g}$ of water had been collected until then, and no further weight gain was registered on the balance. Test III

Because all the water added to the plenum was recovered from this rod in Test II, Test III was not necessary.

$\underline{\text { ROD } 147}$

All four tests designed for Rod 147 were conducted. Test I

The rod was taken directly from cell storage and heated in the test capsule. Pressure, temperature, and weight change as a function of time were 
recorded. As in the initial experiment with Rod 113, no moisture release was measured, although the test temperature was raised to $673 \mathrm{~K}$ and maintained for $1200 \mathrm{~s}$.

Test II

Because no water was released in the first test and again with the prenise that the bulk of the water in the fuel rod was present in the plenum region, a 2.4-mm hole was drilled in the plenum and the test was repeated. As shown in Figure 12, approximately $0.5 \mathrm{~g}$ of water eventually was collected from the rod, although moisture release did not commence until a test temperature of $450 \mathrm{~K}$ was reached. Also, all of the moisture was released within $3000 \mathrm{~s}$, which agrees with results of Test II of Rod 113.

Test III

Next, approximately $10 \mathrm{cin}^{3}(10 \pm 0.2)$ of water were added to the plenum, which was then sealed with a Swagelok fitting. The rod was loaded into the test chamber, and the experiment was performed as specified. The results are

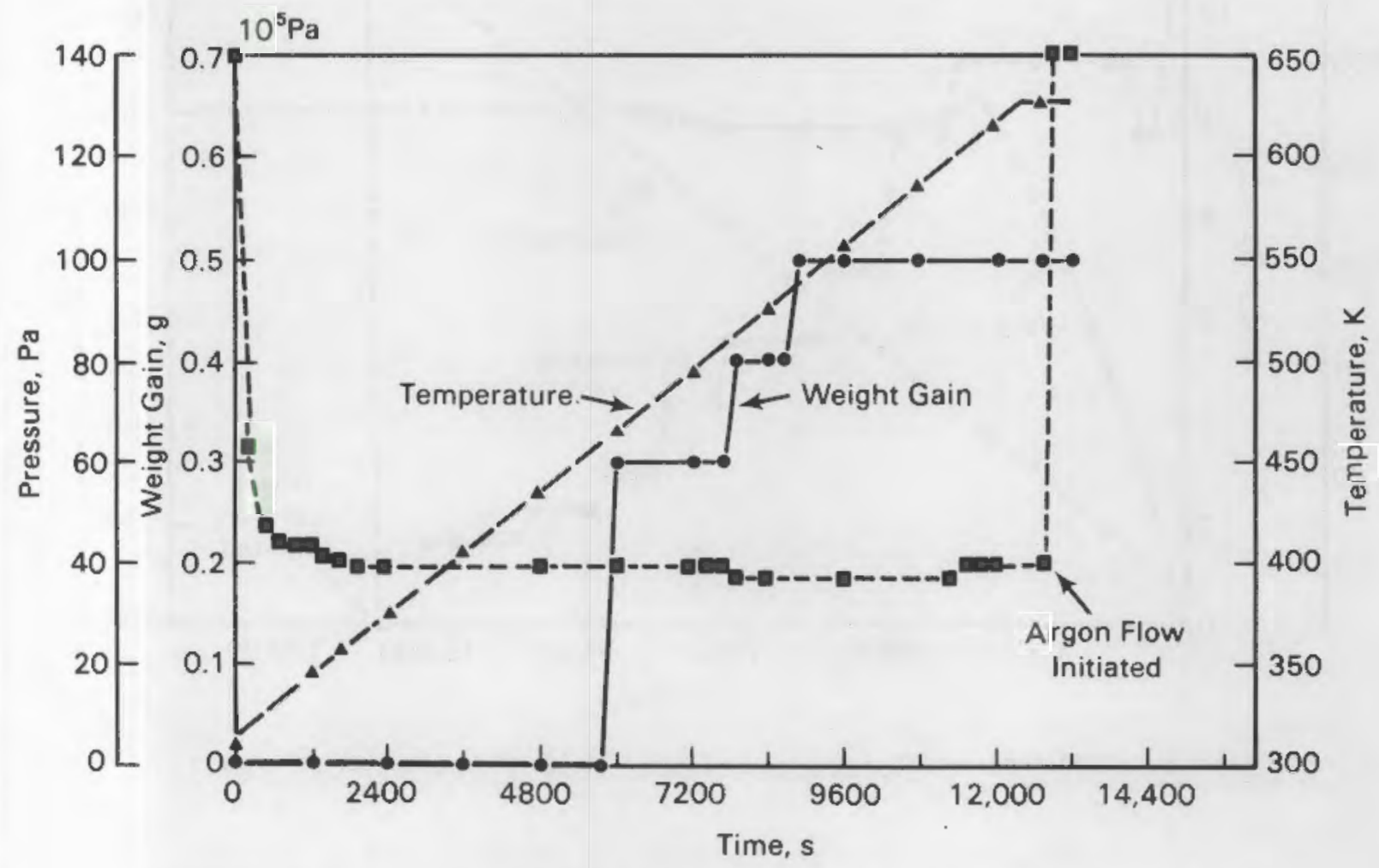

FIGURE 12. Results of Moisture Release Test II with Fuel Rod 147 
shown in Figure 13. Again, most of the added water was released in the first $3600 \mathrm{~s}$; afterwards the rate of release was much slower. The total moisture collected was $10.1 \mathrm{~g}$.

Test IV

In the final test with Rod 147, the plenum hole was sealed with a Swagelok fitting, and the rod was weighed $(5661 \mathrm{~g})$ prior to vacuum injection. It was placed in a stainless steel pressurization tube with a $2.5-\mathrm{cm}$ diameter and a 2.1-mm wall thickness. At one end of the tube, a threaded pipe with a suitable fitting was welded to it through which water was filled in the pressurization tube. At the other end of the tube, a 2.5-cm Swagelok fitting was adapted to fit a $0.8-\mathrm{cm} T$-joint. One branch of the T-joint was connected to the vacuum pump for evacuation; the other branch was connected to a $0.16-\mathrm{cm}-\mathrm{diameter}$ helium pressurization line. The tube was evacuated to $5 \mathrm{~Pa}$ pressure and then

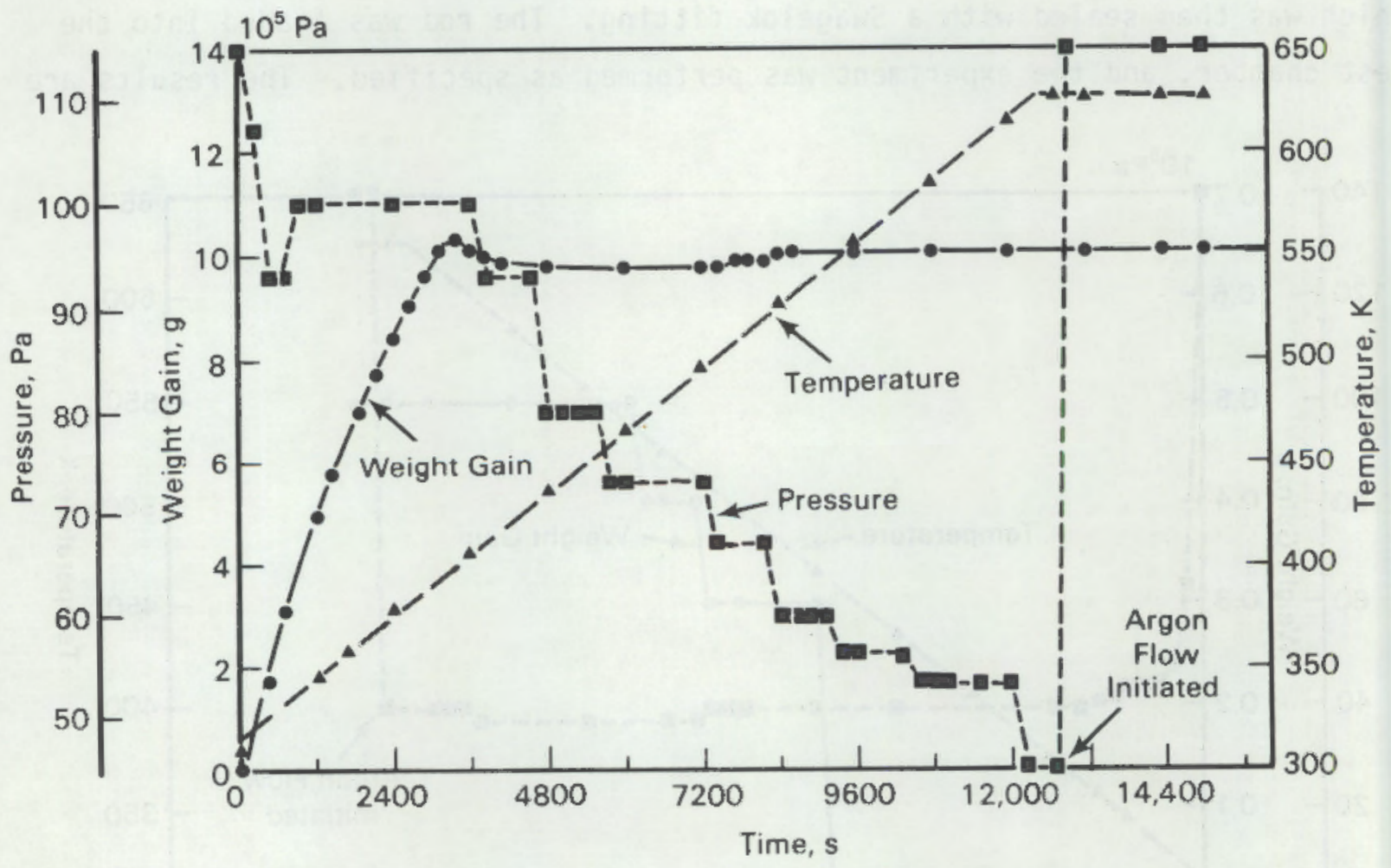

FIGURE 13. Results of Moisture Release Test III with Fuel Rod 147 
filled with water. Next, the water was forced into the rod at a helium pressure of $13.8 \mathrm{MPa}$, and the rod was reweighed $(5715 \mathrm{~g})$. The total water introduced into the rod was $54 \mathrm{~g}$.

Following water-logging, the fuel rod was loaded into the test chamber, and the experiment was started. The results are shown in Figure 14. Inspection of the data shows that over $30 \%$ of the added water was released within the first $3600 \mathrm{~s}$, followed by slower water release. Peaking of the weight curve in Figure 14 was due to saturation of the desiccant. Again, these results agree with results of earlier tests with respect to the rate of moisture release. This agreement is surprising in some respects because water ingress in the present test also could have occurred through the breaches in the fuel rod located away from the plenum. Subsequent water release would require essentially no axial migration, because the plenum was sealed. The insensitivity of the water release rate is further demonstrated by the water-logging tests with Rod 113. During those tests, the water was released from breaches located at least $280 \mathrm{~cm}$ from the sealed plenum where the water was initially injected. Apparently, axial migration of the water readily occurs.

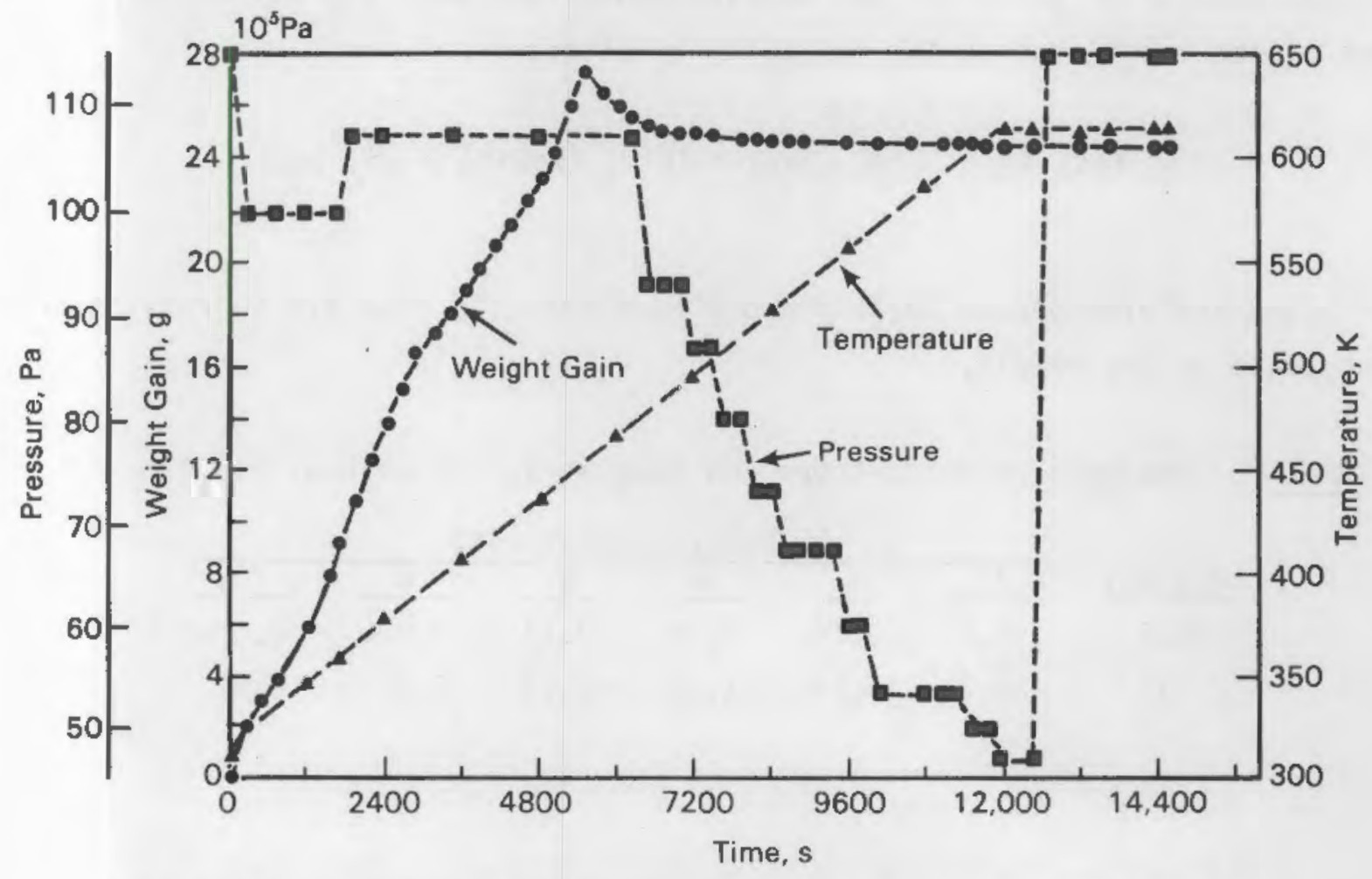

FIGURE 14. Results of Moisture Release Test IV with Fuel Rod 147 
ROD 1937

As required for the test with this fuel rod, $10 \mathrm{~g}$ of water were added through a $1-\mathrm{mm}$ hole in the plenum region, and the plenum was sealed with a Swagelok fitting. A second hole was drilled in the cladding between the seventh and eighth fuel pellets ( $\sim 9 \mathrm{~cm}$ from the bottom of the rod), and the rod was loaded into the furnace tube to start the test. To $424 \mathrm{~K}$ no water release was measured in the drying tower. The hot cell stack alarm was set off, indicating the release of fission gases from the rod (all particulate matter would be captured on the micropore filters located in the hot cell). In addition, the vacuum pump located outside the cell gave a radiation reading of $4 \mathrm{mR} / \mathrm{h}$. As a result, an argon cover gas sample was collected, and the test was discontinued. Analysis of the gas sample (Table 3 ) showed it to contain mainly argon (96.5\%) and helium (3\%) with traces of hydrogen and nitrogen. No xenon or krypton was detected (detection limit $=0.0001 \%$ ). The small amount of hydrogen in the cover gas sample suggests that the bulk of the added water was combined with the fuel. If all of the water had oxidized the Zircaloy cladding, the hydrogen content of the cover gas sample should have been approximately 50 times higher $(\sim 10 \%)$ due to the following reaction:

$$
\mathrm{Zr} \text { (solid) }+2 \mathrm{H}_{2} \mathrm{O} \text { (gas) }=\mathrm{Zr} \mathrm{O}_{2} \text { (solid) }+2 \mathrm{H}_{2} \text { (gas) }
$$

The oxygen and nitrogen in Table 3 could have resulted from air ingression into the capsule or gas sample.

TABLE 3. Analysis of Argon Cover Gas Samples from Fuel Rods 1937 and 512

\begin{tabular}{clllllll} 
& \multicolumn{7}{c}{ Constituent (mol\%) } \\
\cline { 5 - 7 } & $\frac{\mathrm{Ar}}{1937}$ & $\frac{\mathrm{H}}{96.5}$ & $\frac{\mathrm{He}}{0.19}$ & $\frac{\mathrm{N}}{3.16}$ & $\frac{0}{0.13}$ & $\frac{0.006}{0.006}$ & $\frac{\mathrm{CO}_{2}}{0.006}$ \\
512 & 86.3 & 0.24 & 1.05 & 9.53 & 2.90 & 0.02
\end{tabular}


For the test with PWR Rod 512, $6 \mathrm{~g}$ of water were injected through a hole in the plenum region. The plenum was sealed. As before, a second 1-mm hole was drilled in the cladding at approximately $11 \mathrm{~cm}$ from rod bottom (between the seventh and eighth fuel pellets), and the test was started. When the temperature reached $605 \mathrm{~K}$, the hot cell alarm was set off. No water release was measured in the drying tower. The radiation reading at the vacuum pump was $8 \mathrm{mR} / \mathrm{h}$. This test was also discontinued.

Assuming the residual fission gas could be vented out, the plenum seal was removed, and the rod was reheated under vacuum pumping to $673 \mathrm{~K}$ for $600 \mathrm{~s}$. No further gas release was measured, suggesting that the residual fission gas had been released during the test. Hence, the rod was reprepared for a second water-logging experiment. Again, only $6 \mathrm{~g}$ of water could be added to the plenum, which was resealed, and the test was started. This time the furnace temperature was $673 \mathrm{~K}$ when the stack alarm was set off. However, no water release was measured in the drying tower. A cover gas sample was collected, and testing was discontinued. Analysis of the argon cover gas (see Table 3) gave results very similar to those for Rod 1937, except for relatively high values for nitrogen (9.53\%) and oxygen (2.9\%). These high values may be due to inleakage of air in the gas collection system; otherwise, significant fuel oxidation would have occurred in the rod.

The lack of water release during both tests with this fuel rod supports the view that the water is combined with the fuel. Furthermore, it helps to explain the release of residual fission gas following water addition, because the reaction with the water would tend to release gas contained in the pores and bubbles in the fuel. Since such a reaction tends to be diffusion controlled and directly dependent on the amount of water available, fission gas will be released only in the presence of water, as was observed. In the tests of Peehs and Fleisch (1986), the two reactor-breached fuel rods apparently were only partially saturated with water prior to testing. During subsequent heating to $673 \mathrm{~K}$, further oxidation of the fuel took place, and additional fission 
gas was released. The evidence from the present tests also suggests that axial migration of water in LWR fuel rods takes place only if the fuel has been saturated with water and no further oxidation occurs. 


\section{REFERENCES}

Kohli, R., et al. 1985. "The Behavior of Breached Boiling Water Reactor Fuel Rods on Long-Term Exposure to Air and Argon at 598K." Nucl. Technol. 69: 186.

Peehs, M., and J. Fleisch. 1986. "LWR Spent Fuel Storage Behaviour." J. Nucl. Mater. 137:190. 


\section{DISTR IBUTION}

No. of

Copies

OFFSI TE

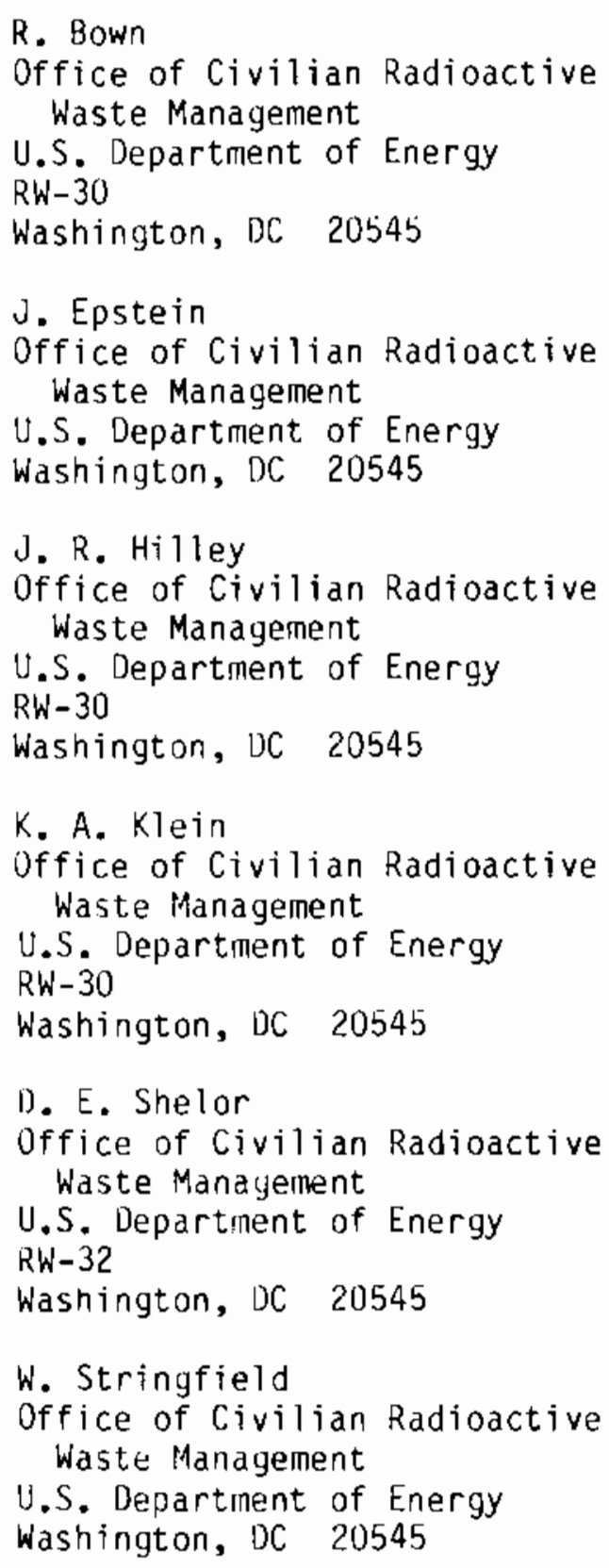

R. Bown

Office of Civilian Radioactive Waste Management

U.S. Department of Energy

$\mathrm{RW}-30$

Washington, DC 20545

J. Epstein

Office of Civilian Radioactive Waste Management

U.S. Department of Energy

Washington, DC 20545

J. R. Hilley

Office of Civilian Radioactive Waste Management

U.S. Department of Energy

$\mathrm{RW}-30$

Washington, UC 20545

K. A. Klein

Office of Civilian Radioactive Waste Management

U.S. Department of Energy

RW-30

Washington, DC 20545

D. E. Shelor

Office of Civilian Radioactive Waste Manayement

U.S. Department of Energy

$\mathrm{RW}-32$

Washington, DC 20545

W. Stringfield

Office of Civilian Radioactive Waste Management

U.S. Department of Energy

Washington, DC 20545

No. of

Copies

\section{J. S. Finucane}

Energy Information

Administration

U.S. Department of Energy

EI -53

Washington, DC 20545

K. G. Golliher

U.S. Department of Energy

Albuquerque Operations Office

Albuquerque, NM 87115

C. P. Gertz

U.S. Department of Energy Idaho Operations Office

550 Second Street

Idaho Falls, ID 83401

D. Vieth

U.S. Department of Energy

Nevada Operations Office

Las Vegas, NV 89114

C. Mat thews

U.S. Departinent of Energy

Oak Ridge Operations Office

P.0. Box E

Oak Ridge, TN 37830

DOE Technical Information Center

B. A. Chin

Mechanical Engineering Dept.

247 Wi lmore Laboratories

Auburn University, AL 36830

M. Sankovich

Babcock \& Wilcox Co.

P.0. Box 1260

Lynchburg, VA 24505 
No. of

Copies

L. A. Walton

Babcock \& Wilcox Co.

P.0. Box 10935

Lynchburg, VA 24506

P. A. File

Baltimore Gas and Electric Co.

Calvert Cliffs Nuclear Power Plant

Lusby, M0 20657

J. A. Carr

Battel le Project Management

Division

office of Nuclear

Waste Isolation

505 King Avenue

Columbus, OH 43201

B. A. Rawles

Battelle Memorial Institute

Office of Nuclear Waste Isolation

$505 \mathrm{King}$ Avenue

Columbus, $\mathrm{OH} 43201$

5 R. Kohli

Battelle Columbus Division

505 King Avenue

Columbus, OH 43201

5 V. Pasupathi

Battelle Columbus Division

$505 \mathrm{King}$ Avenue

Columbus, $\mathrm{OH} 43201$

10 T. W. Wood

Battelle Memorial Institute

Washington Operations

2030 M Street-NW

Suite 800

Washington, DC 20036

G. A. Jownes

BE Inc.

P.0. Box 145

New Ellenton, SC 29809
No. of

Copies

\author{
R. L. Hails \\ Bechtel Power Corporation \\ 15740 Shady Grove Rd. \\ Gaithersburg, MD 20760 \\ D. R. Olander \\ University of California \\ 647 San Fernando Ave. \\ Berkeley, CA 94707 \\ R. Kunita \\ Carolina Power \& Light Co. \\ P.0. Box 1551 \\ Raleigh, NC 27602 \\ G. C. Jobson \\ Chem-Nuclear Systems, Inc. \\ One Greystone West Building \\ 240 Stoneridge Drive, Suite 100 \\ Columbia, SC 29210 \\ N. Fuhrman \\ Combustion Engineering, Inc. \\ 1000 Prospect Hill Road \\ Windsor, CT 06095 \\ R. L. Moscardini \\ Combustion Engineering, Inc. \\ 1000 Prospect Hill Road \\ Windsor, CT 06095 \\ G. P. Wagner \\ Commonwealth Edison \\ Nuclear Stations Oivision \\ P.0. Box 767 \\ Chicago, IL 60690 \\ T. J. Marz \\ Consumers Power Company \\ 1945 W. Parnall Road \\ Jackson, MI 49201 \\ S. J. Raffety \\ Dariland Power Coop. \\ LaCrosse, WI 54601
}


No. of

Copies

R. W. Rasmussen

Duke Power Company

P.0. Box 33189

Charlotte, NC 28242

R. Stanford

Edison Electric Institute

1111 19th St., NW

Washington, DC 20036

D. H. Schoonen

EG\&G Idaho, Inc.

P.0. Box 1625

Idaho Falls, ID 83415

R. F. Williams

Electric Power Research

Institute

P.0. Box 10412

Palo Alto, CA 94303

R. W. Lambert

Electric Power Research Institute

P.0. Box 10412

Palo A1to, CA 94303

J. R. Tomonto

Florida Power \& Light

P.0. Box 013100

Miami, FL 33101

G. T. Zamry

Florida Power \& Light Co. $9250 \mathrm{~W}$. Flagler St.

Miami, FL 33174

B. J. Baxter

GA Technologies Inc.

P.0. Box 81608

San Diego, CA 92138

E. E. Voiland

General Electric Co.

Morris Operation

Morris, IL 60450
No. of

Copies

W. L. Dobson

Gilbert Associates, Inc.

P.0. Box 1498

Reading, PA 19603

V. J. Barnhart

GNS I

135 Darling Dr.

Avon, CT 06001

B. Handly

Houston Lighting \& Power Co.

Nuclear Fuels, Baybrook

P.0. Box 1700

Houston, TX 77001

J. A. McBride

E. R. Johnson Associates, Inc.

11702 Bowman Green Drive

Reston, VA 22090

L. M. Trosten

LeBoeuf, Lamb, Leiby, \& MacRae 1333 New Hampshire Ave. NW Washington, DC 20036

L. D. Ramspott

Lawrence Livermore National Laboratory

P.0. Box 808

Mail Stop L404

Livermore, CA 94550

V. M. Oversby

Waste Package Task, NNWSI

Lawrence Livermore National Laboratory

P.0. Box 808

L206

Livermore, CA 94550

J. H. Garrity

Maine Yankee Atomic Power Co. Edison Drive

August, ME 04336 
No. of

Copies
No. of

Copies
R. T. Haelsig
Nuclear Packaging Inc.
l010S. 336th St.
Federal Way, WA 98003
G. J. Antonucci
NUS Corporation
910 Clopper Rd.
Gathersburg, MD 20878

J. V. Massey

NUTECH Engineers

145 Martinvale Lane

San Jose, CA 95119

J. Van Cleve

Oak Ridge National Laboratory

P.0. Box X

Oak Ridge, TN 37831

M. Litterman
Pacific Gas \& Electric,
Trojan Fuel
l21 S.W. Salmon St.
Portland, OR 97204
M. L. Picklesimer
Pic Products Co.
221 Meadowood Lane
Montevello, AL 35115
Portland General Electric
131 S.W. Salmon Street
Portland, OR 97204
G. C. Allen
Sandia National Laboratory
Transportation Technology Center
P.O. Box 5800
Albuquerque, NM 87185
J. F. Ney
Sandia National Laboratory
Transportation Technology Center
P.0. Box 5800
Albuquerque, NM 87185 
No. of

Copies

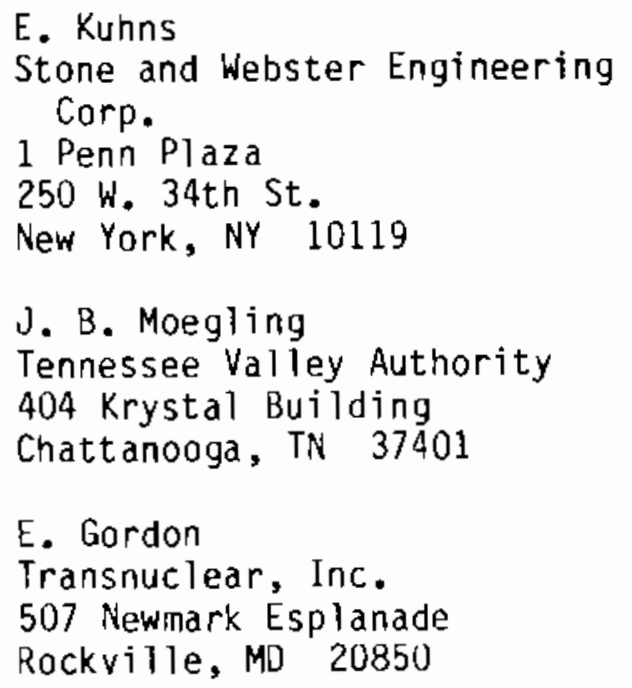

No. of

Copies

\author{
J. Roberts \\ U.S. Nuclear Regulatory \\ Commission \\ Office of Nuclear Materials \\ Safety and Safeguards \\ Washington, DC 20555 \\ L. C. Rouse \\ U.S. Nuclear Regulatory \\ Commission \\ Spent Fuel Storage Installation \\ Division of Fuel Cycle and \\ Material Safety \\ Washington, DC 20555 \\ S. P. Turel \\ U.S. Nuclear Regulatory \\ Commission \\ Office of Nuclear Regulatory \\ Research \\ Washington, DC 20555 \\ W. J. Wachter \\ U.S. Tool and Die, Inc. \\ 4030 Route 8 \\ Allison Park, PA 15101 \\ S. P. Keck \\ Virginia Electric \& Power \\ P.0. Box 26666 \\ Richmond, VA 23261 \\ M. L. Smith \\ Virginia Electric \& Power \\ P.0. Box 26666 \\ Richmond, VA 23261 \\ J. A. Nevshemal \\ Westec Services, Inc. \\ P.0. Box 765 \\ Muscatine, IA 52761-0765 \\ E. S. Bassler \\ Westinghouse Electric Corp. \\ Box 2728 \\ Pittsburgh, PA 15230
}


No. of

Copies

A. R. Hak 1

Westinghouse Electric Corp.

Waste Technology Services Div.

P.0. Box 10864

Pittsburgh, PA 15236

N. Dayem

R. F. Westan $\mathrm{Co}$.

2301 Research Blvd.

Rockville, MD 20850

E. Benz

R. F. Weston Co.

2301 Research Bivd.

Rockville, MD 20850

ONSITE

4 DOE Richland Operations Office

J. P. Collins

R. D. Izatt

D. C. Langstaff

M. J. Plahuta

3 Hanford Engineering Development Laboratory

R. E. Einziger

R. L. Knecht

R. E. Woodley

Rockwell Hanford Company

C. L. Brown
No. of

Copies

64 Pacific Northwest Laboratory

M. J. Apted

W. J. Bailey

J. 0. Barner

G. H. Beeman (10)

B. M. Cole

J. M. Creer

M. D. Freshley

S. R. Gano

E. R. Gilbert (20)

R. J. Guenther

C. M. Heeb

A. B. Johnson, Jr. (5)

C. A. Knox

D. K. Kreid

M. R. Kreiter

J. L. McElroy

G. L. McVay

L. G. Morgan

D. F. Newman

J.T.A. Roberts

K. J. Schneider

D. J. Silviera

L. A. Strope

R. C. Walling

G. D. White

Publishing Coordination (2)

Technical Information (5) 